Original Contribution

\title{
PROTECTIVE EFFECTS OF NATURAL BIO-ANTIOXIDANTS AND THEIR SYNTHETIC ANALOGUES IN EQUIMOLAR BINARY AND TRIPLE MIXTURES
}

\author{
V. D. Kancheva* \\ Institute of Organic Chemistry with Centre of Phytochemistry, Bulgarian Academy of Sciences, \\ Sofia, Bulgaria
}

\begin{abstract}
PURPOSE: Different effects (synergism, additivism or antagonism) of binary and triple mixtures of bioantioxidants with alpha-tocopherol (TOH) and/or ascorbyl palmitate (AscPH) was studied. METHODS: Kinetics of bulk lipid autoxidation at $80^{\circ} \mathrm{C}$ was studied in absence and in presence of equimolar binary mixtures (1:1) with TOH or AscPH and of equimolar triple mixtures (1:1:1) of bio-antioxidants with TOH and $\mathrm{AscPH}$ at concentration of the individual components $0.1 \mathrm{mM}$. Different effects was explain on the basis of the following formulae: A) For binary mixtures: Sinergism: $\mathrm{IP}_{1+2}>\mathrm{IP}_{1}+\mathrm{IP}_{2}$; Additivism: $\mathrm{IP}_{1+2}=\mathrm{IP}_{1}+\mathrm{IP}_{2}$; and Antagonism: $\mathrm{IP}_{1+2}<\mathrm{IP}_{1}+\mathrm{IP}_{2}$; B) For triple mixtures: Sinergism: $\mathrm{IP}_{\Sigma}>\Sigma \mathrm{IP}_{\mathrm{i}}$; Additivism $\mathrm{IP}_{\Sigma}=\Sigma \mathrm{IP}_{\mathrm{i}}$; and Antagonism: $\mathrm{IP}_{\Sigma}<\Sigma \mathrm{IP}_{\mathrm{i}}$, where $\mathrm{i}=1,2,3$ components. $\mathrm{TOH}$ content in the studied mixtures at different reaction time of lipid autoxidation was monitored by using HPLC method. RESULTS: Mechanisms of action of bio-antioxidants in binary and triple mixtures is presented. It has been proven that the synergism obtained between binary and triple mixtures is due to the significant effect of TOH regeneration. CONCLUSIONS: The practical application of results obtained is discussed.
\end{abstract}

Key words: protective effects, antioxidant mixtures, bio-antioxidants, HPLC.

\section{INTRODUCTION}

Biologically active compounds with antioxidant potential, i.e. bio-antioxidants (natural and their synthetic analogues) have a wide range of applications. They are important drugs, antibiotics, agrochemical substitutes, and food preservatives. Many of the drugs today are synthetic modifications of naturally obtained substances with both activities-biological and antioxidant. The most important known natural bio-antioxidants are flavonoids and phenolic acids. Last decades the attention of scientists was focused on design of new bio-antioxidants. The idea is to combine in one molecule by a specific synthetic way various functional fragments, responsible for biological and antioxidant activities for the individual compounds. When it

*Correspondence to: Assoc. Prof. Dr. Vessela D. Kancheva, Lipid Chemistry Department, Institute of Organic Chemistry with Centre of Phytochemistry, Bulgarian Academy of Sciences, Acad. "Georgi Bonchev” Str., Bl. 9, 1113 Sofia;Phone: 02-9606187; Fax:02-8700-225; e-mail: vedeka@abv.bg is not possible it can be used so called bioantioxidant compositions - by mixtures (double or triple) of biologically active compounds, antioxidants, synergists, which are multifunctional (1-3).

Nowadays bio-antioxidants play an important role in prevention of human diseases as components of food additives and for treatment of different diseases as monotherapy or in complex therapy with drugs. It has been found that in the first stage of the development of atherosclerosis the system works in its normal regime. The introduction of antioxidants in the affected body normalizes not only the peroxide oxidation, but also the lipid content. Monotherapy with antioxidants also is used in early stage of atherosclerosis and in oncology. In this case the antioxidants are used at high concentration. There are a lot of reports about combination therapy with drugs and antioxidants, but in this case antioxidants are mainly used as additives in the complex tumor therapy - the antioxidant is in low 
concentrations. In this respect the medical treatment of most of diseases includes formulations based on a combination of traditional drugs with targeted functionality and different antioxidants $(2,4)$.

For that reason, it is of importance to be studied different effects of equimolar binary and triple mixtures of some known and new bioantioxidants with $\alpha$-tocopherol (TOH) and ascorbyl palmitate (AscPH). The aim of this study is to check which antioxidant compositions are able to ensure the highest lipid oxidation stability and different effects (synergism, additivism or antagonism) of binary and triple mixtures of bio-antioxidants with $\alpha$-tocopherol $(\mathrm{TOH})$ and/or ascorbyl palmitate (AscPH).

\section{MATHERIAL AND METHODS}

DL- $\alpha$-tocopherol (TOH), ferulic acid (FA), caffeic acid (CA), sinapic acid(SA), butylated hydroxytoluene (BHT), tret-butylhydroquinone (TBHQ) and ascorbyl palmitate (AscPH) were from from E. Merck (Germany). Quercetin $(\mathrm{Qu})$, luteolin $(\mathrm{Lu})$ and ritun $(\mathrm{Ru})$ were isolated earlier from Carthamus lanatus L. (5). 7,8-dihydroxy-5methyl-coumarin $\left(\mathrm{Cum}_{1}\right)$, 6,7,-dihydroxy-4methyl-coumarin $\left(\mathrm{Cum}_{2}\right)$ and 7-Hydroxy-4methyl-coumarin $\left(\mathrm{Cum}_{3}\right)$ were synthesized from University of Delhi, India and previously reported (6). Dehydrozingerone $\left(\mathrm{M}_{1} \mathrm{OH}\right)$, zingerone $\left(\mathrm{M}_{2} \mathrm{OH}\right)$, dimer of dehydrozingerone $\mathrm{D}_{1}(\mathrm{OH})_{2}$, dimer of zingerone $\mathrm{D}_{2}(\mathrm{OH})_{2}$ and dimer of ferulic acid (DFA) was synthesized from CNR Institute of biomolechular chemistry, Italy and reported previously (7). A Shimadzu HPLC system (Shimadzu Corp., Kyoto, Japan), consisting of a LC-10AD pump, SCTL 10A system controller and SPD-M 10A photodiode array detector was employed. A detailed protocol can be seen in Ref. (8)

Lipid samples. Triacylglycerols of commercially available sunflower oil (TGSO) were cleaned from pro- and anti-oxidants by adsorption chromatography and stored under nitrogen at minus $20^{\circ} \mathrm{C}$. Lipid samples containing various inhibitors were prepared directly before use. Aliquots of the antioxidant solutions in purified acetone were added to the lipid sample. Solvents were removed under a nitrogen flow.

Lipid autoxidation. The process was carried out in a thermostatic bath at $80{ }^{\circ} \mathrm{C}\left( \pm 0.2{ }^{\circ} \mathrm{C}\right)$ by blowing air through the samples in special vessels. The oxidation process was monitored by withdrawing samples at measured time intervals and subjecting them to iodometric determination of the primary products (lipid hydroxyperoxides, $\mathrm{LOOH}$ ) concentration, i.e. the peroxide value (PV) (9). All kinetic data are expressed as the average of two independent measurements which were processed using the computer programs Origin 6.1 and Microsoft Excel-97.

Synergism, additivism, antagonism. If two or more antioxidants are added to oxidizing substrates, their combined inhibitory effect can be synergistic, additive, or antagonistic $(9,10)$.

Synergism - the inhibiting effect of the binary and triple mixtures $\left(\mathrm{IP}_{\Sigma}\right)$ is higher than the sum of the induction periods of the individual phenolic antioxidants $\left(\mathrm{IP}_{\mathrm{i}}\right)$, i.e. $\mathrm{IP}_{\Sigma}>\Sigma \mathrm{IP}_{\mathrm{i}}$, where $\mathrm{i}$ $=1,2,3$. Additivism - the inhibiting effect of the binary and triple mixtures $\left(\mathrm{IP}_{\Sigma}\right)$ is equal to the sum of the induction periods of the individual phenolic antioxidants, i.e. $\operatorname{IP}_{\Sigma}=\Sigma \mathrm{IP}_{\mathrm{i}}$. Antagonism - the inhibiting effect of the $\left(\mathrm{IP}_{\Sigma}\right)$ is lower than the sum of the induction periods of the individual phenolic antioxidants, i.e. $\mathrm{IP}_{\Sigma}<$ $\Sigma \mathrm{IP}_{\mathrm{i}}$. The percent of the synergism was calculated according to the formulae created from Frankel (4) for the binary mixtures and updated for triple mixtures by us: \% Synergism $=100\left[\left(\mathrm{IP}_{\Sigma}-\Sigma \mathrm{IP}_{\mathrm{i}}\right) / \Sigma \mathrm{IP}_{\mathrm{i}}\right]$. We also suggest for the first time by the similar way the calculation of $\%$ antagonism by the formulae: $\%$ Antagonism $=100\left[\left(\Sigma \mathrm{IP}_{\mathrm{i}}-\mathrm{IP}_{\Sigma}\right) / \mathrm{IP}_{\Sigma}\right]$.

Statistical analysis of IP determination. The standard deviation (SD) for different mean values of IP was (in h): IP=2.0, SD=0.2; IP=5.0, SD=0.3; $\mathrm{IP}=15.0, \quad \mathrm{SD}=1.0 ; \quad \mathrm{IP}=25, \quad \mathrm{SD}=1.5 ; \quad \mathrm{IP}=50.0$, $\mathrm{SD}=3.0$. The $\mathrm{SD}$ of $\mathrm{PV}$ determination (in $\mathrm{meq} / \mathrm{kg}$ ), according to the modified iodometric method for different mean values of $\mathrm{PV}$, was: $\mathrm{PV}=12.0$, $\mathrm{SD}=1.0 ; \mathrm{PV}=30.0, \mathrm{SD}=2.0 ; \mathrm{PV}=70.0, \quad \mathrm{SD}=5.0$; $\mathrm{PV}=150.0, \mathrm{SD}=10 ; \mathrm{PV}=250.0, \mathrm{SD}=20$. The $\mathrm{R}_{\mathrm{A}}$ and $\mathrm{R}_{\mathrm{C}}$ were quite constant varying by less than $2 \%$.

\section{RESULTS AND DISCUSSION Protective effects of binary mixtures of flavonoids}

Flavonoids are the well-known natural bioantioxidants, because they are powerful antioxidants and possess various biological activities. A lot of studies of scientists are focused on the structure-activity relationship of these interesting compounds. 


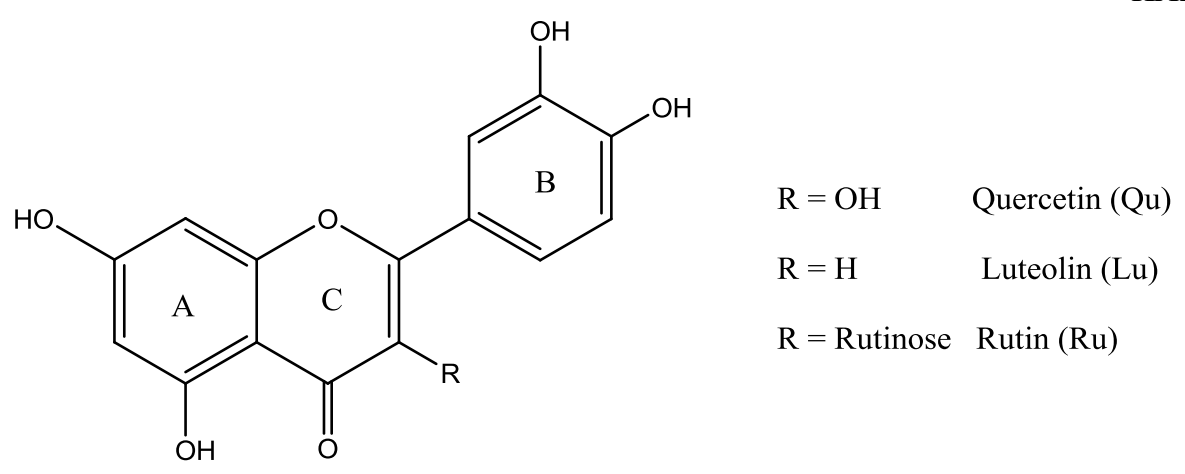

KANCHEVA V.D.

Figure 1. Structures of flavonoids: quercetine $(\mathrm{Qu})$, luteoline $(\mathrm{Lu})$ and rutine $(\mathrm{Ru})$

Figure 1 presents the structures of selected flavonoids under study. In order to check the possible synergism between two flavonoid aglicones $\mathrm{Qu}$ and $\mathrm{Lu}$ binary mixtures with equimolar concentrations $(0.1 \mathrm{mM})$ were prepared and their effect on the kinetics of lipid autoxidation was studied (Figure 2 and Table 1). The mixtutre of $\mathrm{Qu}+\mathrm{Lu}$ showed almost 7-fold higher inhibiting effect than $\mathrm{Lu}$ and 1.4-fold higher inhibiting effect than Qu. The mixture of flavonoid aglycone and glyceride $\mathrm{Qu}+\mathrm{Ru}$ showed a lower oxidation stability of lipid substrate than of $\mathrm{Qu}$ alone, however, almost 3fold higher effect than $\mathrm{Ru}$. Evidently, the addition of Ru to Qu not only didn't improve the antioxidant efficiency of $\mathrm{Qu}$ but even led to decrease of the antioxidant potential of the aglycon. Consequently, these both mixtures of $\mathrm{Qu}+\mathrm{Lu}$ and $\mathrm{Qu}+\mathrm{Ru}$ show no synergism; furthermore they showed an antagonism between flavonoids. These results manifested that these flavonoid aglycons ( $\mathrm{Qu}$ and $\mathrm{Lu}$ ) and glycoside $(\mathrm{Ru})$ must be used as individual antioxidants, not in mixtures (5).

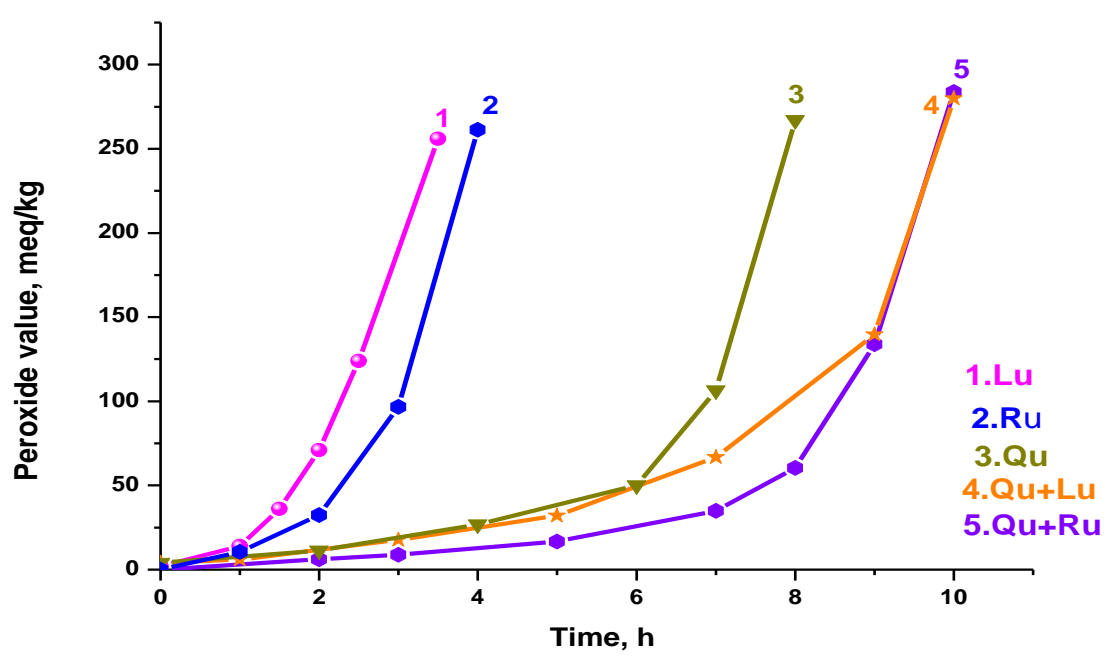

Figure 2. Kinetic curves of lipid hydroperoxides accumulation during TGSO autoxidation at $80^{\circ} \mathrm{C}$ in presence of $0.1 \mathrm{mM}$ Luteolin $(\mathrm{Lu})$, Rutin $(\mathrm{Ru})$, Quercetin $(\mathrm{Qu})$ and of their equimolar (1: 1) binary mixtures $(\mathrm{Lu}+\mathrm{Qu})$ and $(\mathrm{Qu}+\mathrm{Ru})$

As we can see from the Figure 3 and Table 1 the equimolar binary mixtures of flavonoids and TOH demonstrated a synergism between the components: $47 \%$ for $\mathrm{Qu}+\mathrm{TOH}, 19 \%$ for $\mathrm{Lu}+\mathrm{TOH}$ and $87 \%$ for $\mathrm{Ru}+\mathrm{TOH}$.

It is found that the lipid oxidation stability (presented as protection factor, PF in presence of flavonoids studied) decreases in the order: PF: $22.8(\mathrm{Qu}+\mathrm{TOH})>19.2(\mathrm{Ru}+\mathrm{TOH})>15.1$ $(\mathrm{Lu}+\mathrm{TOH})>8.1(\mathrm{TOH})>7.6(\mathrm{Qu})>2.1(\mathrm{Ru})>$ $1.7(\mathrm{Lu})$. New mechanism of action of flavonoids and tocopherol in binary mixtures is presented. 
KANCHEVA V.D.

Table 1. Inhibiting efficiency of various binary mixtures of two (1 and 2) antioxidants in equimolar concentrations $(0.1 \mathrm{mM})$ and $1: 1$ ratio, $80^{\circ} \mathrm{C}$, during TGSO autoxidation $\left.\left(I P_{c}=1.7 \pm 0.2\right) \mathrm{h}, R_{c}=1.210^{-6} \mathrm{M} / \mathrm{s}\right)$

\begin{tabular}{|c|c|c|c|c|c|}
\hline Binary mixtures & $\begin{array}{l}\mathbf{I P}_{1+2} \\
\mathbf{h}\end{array}$ & $\begin{array}{l}\text { IP }_{1} \\
\text { h }\end{array}$ & $\begin{array}{l}\mathbf{I P}_{2} \\
\mathrm{~h}\end{array}$ & $\begin{array}{l}\text { Synergism/Additi- } \\
\text { vism/Antagonism }\end{array}$ & $\begin{array}{l}\text { \%Syn } \\
\text { \%Ant }\end{array}$ \\
\hline $\mathrm{Qu}(1)+\mathrm{Lu}(2)(\mathrm{Qu}+\mathrm{Lu})$ & $7.5 \pm 0.8$ & $9.9 \pm 0.9$ & $2.2 \pm 0.2$ & Ant $\quad \mathrm{IP}_{1+2}<\left(\mathrm{IP}_{1}+\mathrm{IP}_{2}\right)$ & $61 \%$ \\
\hline $\mathrm{Qu}(1)+\mathrm{Ru}(2)(\mathrm{Qu}+\mathrm{Ru})$ & $8.3 \pm 0.8$ & $9.9 \pm 0.9$ & $2.7 \pm 0.2$ & Ant $\quad \mathrm{IP}_{1+2}<\left(\mathrm{IP}_{1}+\mathrm{IP}_{2}\right)$ & $52 \%$ \\
\hline $\mathrm{Qu}(1)+\mathrm{TOH}(2)(\mathrm{Qu}+\mathrm{TOH})$ & $29.7 \pm 1.5$ & $9.9 \pm 0.9$ & $10.5 \pm 0.9$ & Sin $\quad \mathrm{IP}_{1+2}>\left(\mathrm{IP}_{1}+\mathrm{IP}_{2}\right)$ & $46 \%$ \\
\hline $\mathrm{Lu}(1)+\mathrm{TOH}(2)(\mathrm{Lu}+\mathrm{TOH})$ & $15.1 \pm 0.9$ & $2.4 \pm 0.2$ & $10.5 \pm 0.9$ & $\operatorname{Sin} \quad \mathrm{IP}_{1+2}>\left(\mathrm{IP}_{1}+\mathrm{IP}_{2}\right)$ & $19 \%$ \\
\hline $\mathrm{Ru}(1)+\mathrm{TOH}(2)(\mathrm{Ru}+\mathrm{TOH})$ & $24.9 \pm 1.5$ & $2.7 \pm 0.2$ & $10.5 \pm 0.9$ & $\operatorname{Sin} \quad \mathrm{IP}_{1+2}>\left(\mathrm{IP}_{1}+\mathrm{IP}_{2}\right)$ & $87 \%$ \\
\hline $\mathrm{CA}(1)+\mathrm{TOH}(2)(\mathrm{CA}+\mathrm{TOH})$ & $20.4 \pm 1.5$ & $9.8 \pm 0.9$ & $10.5 \pm 0.9$ & Add $\quad \mathrm{IP}_{1+2}=\left(\mathrm{IP}_{1}+\mathrm{IP}_{2}\right)$ & - \\
\hline $\mathrm{SA}(1)+\mathrm{TOH}(2)(\mathrm{SA}+\mathrm{TOH})$ & $16.1 \pm 0.9$ & $5.3 \pm 0.5$ & $10.5 \pm 0.9$ & $\mathrm{IP}_{1+2}>\left(\mathrm{IP}_{1}+\mathrm{IP}_{2}\right)$ & $2 \%$ \\
\hline $\mathrm{BHT}(1)+\mathrm{TOH}(2)(\mathrm{BHT}+\mathrm{TOH})$ & $21.5 \pm 1.5$ & $7.5 \pm 0.5$ & $10.5 \pm 0.9$ & Sin $\quad \mathrm{IP}_{1+2}>\left(\mathrm{IP}_{1}+\mathrm{IP}_{2}\right)$ & $19 \%$ \\
\hline TBHQ (1)+ TOH (2) (TBHQ + TOH) & $26.1 \pm 1.5$ & $7.9 \pm 0.5$ & $10.5 \pm 0.9$ & Sin $\quad \mathrm{IP}_{1+2}>\left(\mathrm{IP}_{1}+\mathrm{IP}_{2}\right)$ & $44 \%$ \\
\hline $\mathrm{Cum}_{2}(1)+\mathrm{TOH}(2)\left(\mathrm{Cum}_{2}+\mathrm{TOH}\right)$ & $12.7 \pm 0.9$ & $7.1 \pm 0.5$ & $10.5 \pm 0.9$ & Ant $\quad \mathrm{IP}_{1+2}<\left(\mathrm{IP}_{1}+\mathrm{IP}_{2}\right)$ & $39 \%$ \\
\hline $\mathrm{Cum}_{1}(1)+\mathrm{TOH}(2)\left(\mathrm{Cum}_{1}+\mathrm{TOH}\right)$ & $14.2 \pm 0.9$ & $2.0 \pm 0.2$ & $10.5 \pm 0.9$ & Sin $\quad \mathrm{IP}_{1+2}>\left(\mathrm{IP}_{1}+\mathrm{IP}_{2}\right)$ & $14 \%$ \\
\hline $\mathrm{Cum}_{3}(1)+\mathrm{TOH}(2)(\mathrm{Cum} 3+\mathrm{TOH})$ & $11.8 \pm 0.9$ & $1.5 \pm 0.2$ & $10.5 \pm 0.9$ & Add $\quad \mathrm{IP}_{1+2}=\left(\mathrm{IP}_{1}+\mathrm{IP}_{2}\right)$ & - \\
\hline $\mathrm{SA}(1)+\mathrm{TOH}(2)(\mathrm{SA}+\mathrm{TOH})^{*}$ & $45.0 \pm 1.0$ & $8.5 \pm 0.5$ & $21.0 \pm 1.5$ & Sin $\quad \mathrm{IP}_{1+2}>\left(\mathrm{IP}_{1}+\mathrm{IP}_{2}\right)$ & $52 \%$ \\
\hline $\mathrm{M}_{1} \mathrm{OH}(1)+\mathrm{TOH}(2)\left(\mathrm{M}_{1} \mathrm{OH}+\mathrm{TOH}\right)$ & $14.8 \pm 0.8$ & $1.3 \pm 0.2$ & $10.5 \pm 0.9$ & Sin $\quad \mathrm{IP}_{1+2}>\left(\mathrm{IP}_{1}+\mathrm{IP}_{2}\right)$ & $25 \%$ \\
\hline $\mathrm{D}_{1}(\mathrm{OH})_{2}(1)+\mathrm{TOH}(2)\left(\mathrm{D}_{1}(\mathrm{OH})_{2}+\mathrm{TOH}\right)$ & $13.2 \pm 0.8$ & $3.2 \pm 0.2$ & $10.5 \pm 0.9$ & Add $\quad \mathrm{IP}_{1+2}=\left(\mathrm{IP}_{1}+\mathrm{IP}_{2}\right)$ & - \\
\hline $\mathrm{M}_{2} \mathrm{OH}(1)+\mathrm{TOH}(2)\left(\mathrm{M}_{2} \mathrm{OH}+\mathrm{TOH}\right)$ & $10.3 \pm 0.8$ & $1.3 \pm 0.2$ & $10.5 \pm 0.9$ & $\mathrm{IP}_{1+2}<\left(\mathrm{IP}_{1}+\mathrm{IP}_{2}\right)$ & $15 \%$ \\
\hline $\mathrm{D}_{2}(\mathrm{OH})_{2}(1)+\mathrm{TOH}(2)\left(\mathrm{D}_{1}(\mathrm{OH})_{2}+\mathrm{TOH}\right)$ & $10.9 \pm 0.8$ & $2.0 \pm 0.2$ & $10.5 \pm 0.9$ & Ant $\quad \mathrm{IP}_{1+2}<\left(\mathrm{IP}_{1}+\mathrm{IP}_{2}\right)$ & $15 \%$ \\
\hline $\mathrm{FA}(1)+\mathrm{TOH}(2)(\mathrm{FA}+\mathrm{TOH})$ & $18.5 \pm 0.8$ & $1.9 \pm 0.3$ & $10.5 \pm 0.9$ & Sin $\quad \mathrm{IP}_{1+2}>\left(\mathrm{IP}_{1}+\mathrm{IP}_{2}\right)$ & $49 \%$ \\
\hline $\mathrm{DFA}(1)+\mathrm{TOH}(2)(\mathrm{DFA}+\mathrm{TOH})$ & $21.5 \pm 0.8$ & $2.0 \pm 0.3$ & $10.5 \pm 0.9$ & Sin $\quad \mathrm{IP}_{1+2}>\left(\mathrm{IP}_{1}+\mathrm{IP}_{2}\right)$ & $71 \%$ \\
\hline
\end{tabular}

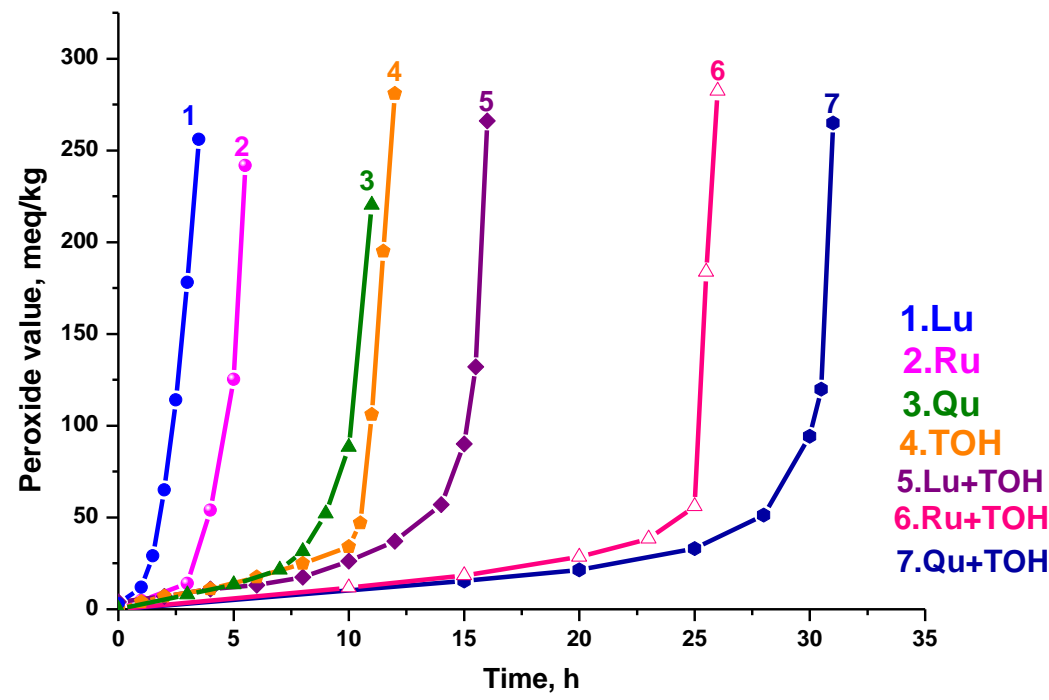

Figure 3. Kinetic curves of lipid hydroperoxides accumulation during TGSO autoxidation at $80^{\circ} \mathrm{C}$ in presence of $0.1 \mathrm{mM}$ Luteolin $(\mathrm{Lu})$, Rutin $(\mathrm{Ru})$, Quercetin $(\mathrm{Qu}), \alpha$-Tocopherol $(\mathrm{TOH})$ and of their equimolar (1:1) binary mixtures $(\mathrm{Lu}+\mathrm{TOH}),(\mathrm{Qu}+\mathrm{TOH})$ and $(\mathrm{Ru}+\mathrm{TOH})$ 
For that reason the following reactions of binary mixtures of flavonoids (for example quercetin) $\mathrm{Qu}(\mathrm{OH})_{2}, \quad \alpha$-tocopherol, $\left.\mathrm{TOH}\right)$ and of their radicals - tocopheryl radical (TO•) and semiquinone radicals $\mathrm{Qu}(\mathrm{OH}) \mathrm{O} \bullet$ with lipid peroxide radicald $\left(\mathrm{LO}_{2} \bullet\right)$ and reactions of homoand cross-recombination and disproportionation rections, responsable to different effects observed are presented:

\section{- $\quad$ Reactions of Quercetin $\left(\mathrm{Qu}(\mathrm{OH})_{2}\right.$ and its radicals}

$\mathrm{Qu}(\mathrm{OH})_{2}+\mathrm{LO}_{2}{ }^{\bullet} \rightarrow \mathrm{Qu}(\mathrm{OH}) \mathrm{O}^{\bullet}+\mathrm{LOOH}$ (H atom transfer $)$

$\mathrm{Qu}(\mathrm{OH}) \mathrm{O}^{\bullet}+\mathrm{LO}_{2}{ }^{\bullet} \rightarrow \mathrm{Qu}(\mathrm{OH}) \mathrm{O}-\mathrm{OOL}$ (cross-recombination reaction with quinolide peroxides formation) $\mathrm{Qu}(\mathrm{OH}) \mathrm{O}-\mathrm{OOL}+\mathrm{LO}_{2}^{\bullet} \rightarrow \mathrm{Qu}(\mathrm{O} \bullet \mathrm{O}-\mathrm{OOL}+\mathrm{LOOH}(\mathrm{H}$ atom transfer $)$

$\mathrm{Qu}\left(\mathrm{O} \bullet \mathrm{O}-\mathrm{OOL}+\mathrm{LO}_{2}{ }^{\circ} \rightarrow \mathrm{Qu}(\mathrm{OOOL})_{2}\right.$ (cross-recombination reaction with quinolide peroxides formation)

$2 \mathrm{Qu}(\mathrm{OH}) \mathrm{O}^{\bullet} \rightarrow \mathrm{Qu}(\mathrm{OH})_{2}+\mathrm{QuO}_{2}$ (homo-dissproportionation reaction with $\mathrm{Qu}(\mathrm{OH})_{2}$ regeneration and ortho-quinone formation $\mathrm{QuO}_{2}$ )

\section{$\mathrm{TOH}+\mathrm{LO}_{2}{ }^{\bullet} \rightarrow \mathrm{TO}^{\bullet}+\mathrm{LOOH}(\mathrm{H}$ atom transfer $)$}

$\mathrm{TO}^{\bullet}+\mathrm{LO}_{2}{ }^{\bullet} \rightarrow \mathrm{TO}-\mathrm{OOL}$ (cross-recombination reaction with quinolide peroxides formation)

$2 \mathrm{TO}^{\circ} \rightarrow \mathrm{TOH}+($ homo-dissproportionation reaction with $\mathrm{TOH}$ regeneration and tocopheryl-methylenequinone formation $T=O$ )

- $\quad$ Reactions between $\mathrm{Qu}(\mathrm{OH})_{2}$ and TOH and between their radicals

$\mathrm{Qu}(\mathrm{OH}) \mathrm{O}^{\bullet}+\mathrm{TOH} \rightarrow \mathrm{Qu}(\mathrm{OH})_{2}+\mathrm{TO}^{\bullet}\left(\mathrm{H}\right.$ atom transfer with $\mathrm{Qu}(\mathrm{OH})_{2}$ regeneration $)$

$\mathrm{TO}^{\bullet}+\mathrm{Qu}(\mathrm{OH})_{2} \rightarrow \mathrm{TOH}+\mathrm{Qu}(\mathrm{OH}) \mathrm{O}^{\bullet}$ (H atom transfer with regeneration of $\left.\mathrm{TOH}\right)$

$\mathrm{TO}^{\bullet}+\mathrm{Qu}(\mathrm{OH}) \mathrm{O}^{\bullet} \rightarrow \mathrm{TOH}+\mathrm{QuO}_{2}$ (cross-dissproportionation reaction with regeneration of TOH and ortho-quinone formation)

$\mathrm{TO}^{\bullet}+\mathrm{Qu}(\mathrm{OH}) \mathrm{O}^{\bullet} \rightarrow \mathrm{Qu}(\mathrm{OH})_{2}+\mathrm{T}=\mathrm{O}$ (cross-dissproportionation reaction with regeneration of $\mathrm{Qu}(\mathrm{OH})_{2}$ and tocopheryl-methylene-quinone formation $T=O)$

$\mathrm{TO}^{\bullet}+\mathrm{Qu}(\mathrm{OH}) \mathrm{O}^{\bullet} \rightarrow$ products (cross-recombination without regeneration)

Scheme 1. The reaction mechanism of action of binary mixtures of quercetin and $\alpha$-tocopherol

$\mathrm{H}$-atom transfer and cross-disproportionation reactions are responsible for the synergism obtained; however, reaction of crossrecombination is responsible to the antagonism observed. Table $\mathbf{2}$ presents results about differences in $\mathrm{O}-\mathrm{H}$ bond dissociation enthalpies (BDE) of $\mathrm{Qu}, \mathrm{Lu}$ and $\mathrm{Ru}$ and $\mathrm{TOH}$, which are the suitable theoretical descriptor for explanation (and probably for prediction) of the effects of binary mixtures. It is seen that in case when $\triangle \mathrm{BDE}>0$ it is observed a synergism, and in case of $\triangle \mathrm{BDE}<0$ an antagonism, respectively.
Protective effects of binary mixtures of cinnamic acids and standard antioxidants

Cinnamic acids are biological precursors of coumarins and chalcones and are widely distributed in the plant kingdom. We studied the effects of equimolar binary mixtures at $0.1 \mathrm{mM}$ concentrations of cinnamic acids - caffeic (CA), sinapic (SA) and ferulic (FA) as well as of standard antioxidants - butylated hydroxyl toluene (BHT) and tret-butylhydroquinone (TBHQ) with tocopherol (TOH) (Figure 4).

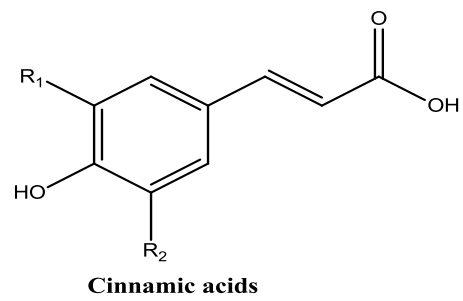

$$
\begin{array}{lll}
\mathrm{R}_{1}=\mathrm{H} & \mathrm{R}_{2}=\mathrm{OH} & \mathrm{CA} \\
\mathrm{R}_{1}=\mathrm{H} & \mathrm{R}_{2}=\mathrm{CH}_{3} & \mathrm{FA} \\
\mathrm{R}_{1}=\mathrm{CH}_{3} & \mathrm{R}_{2}=\mathrm{CH}_{3} & \mathrm{SA}
\end{array}
$$
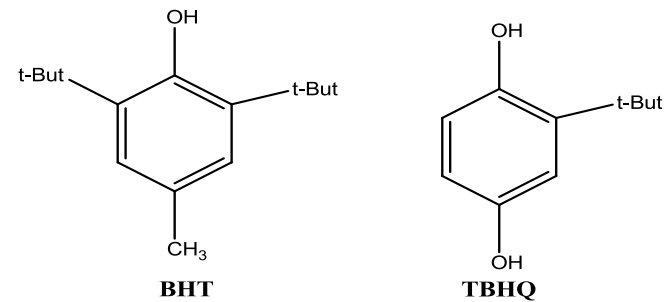

Figure 4. Structures of cinnamic acids, studied: caffeic acid (CA), ferulic acid (FA) and synaptic acid (SA); and of standard antioxidants studied: butylated hydroxytoluene (BHT) and tret-butylhydroquinone (TBHQ)

Figure 5 presents the kinetics of lipid autoxidation in presence of studied cinnamic acids and standard antioxidants as individual compounds and in equimolar binary mixtures with $\mathrm{TOH}$. 


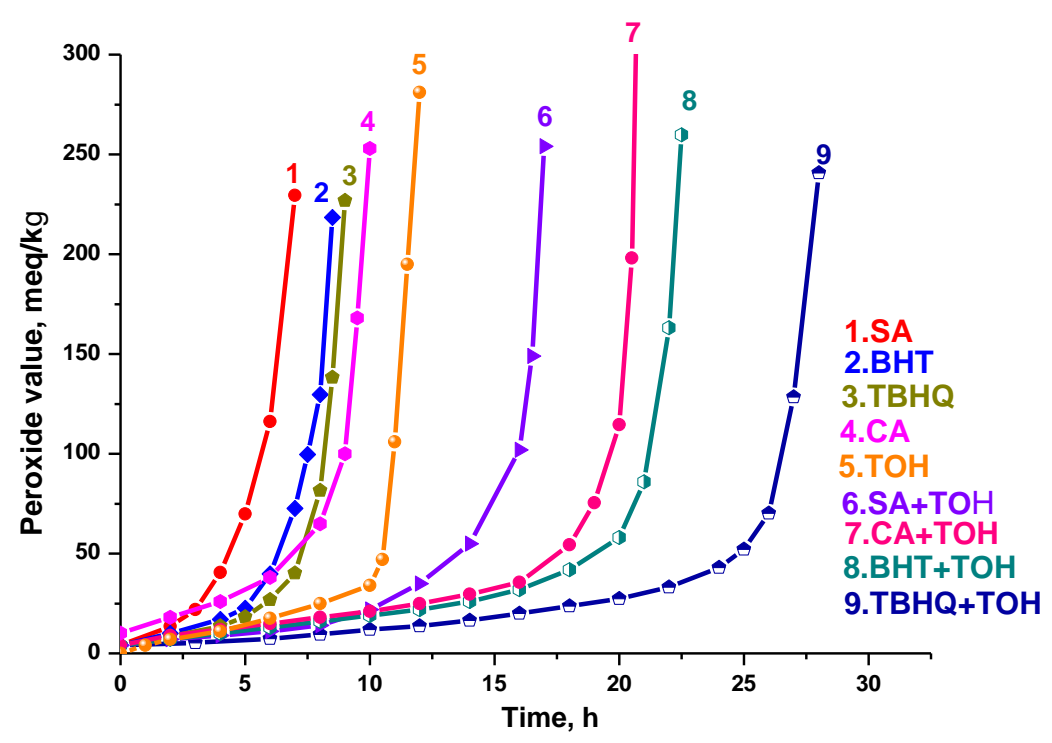

Figure 5. Kinetic curves of lipid hydroperoxides accumulation during TGSO autoxidation at $80^{\circ} \mathrm{C}$ in presence of $0.1 \mathrm{mM}$ sinapic acid (SA), butylated hydroxytoluene (BHT), tretbutylated hydroquinone (TBHQ), caffeic acid (CA), $\alpha$-tocopherol (TOH) and of their equimolar (1:1) binary mixtures (SA+TOH), (BHT+TOH), (TBHQ+TOH), and $(\mathrm{CA}+\mathrm{TOH})$

The following order of lipid oxidation stability was found:

$(\mathrm{TBHQ}+\mathrm{TOH})>(\mathrm{BHT}+\mathrm{TOH})>(\mathrm{CA}+\mathrm{TOH})>$ $(\mathrm{SA}+\mathrm{TOH})>\mathrm{TOH}>\mathrm{CA}>\mathrm{TBHQ} \geq \mathrm{BHT}>\mathrm{SA}$

Tables 1 and 3 present the result of effects observed in these binary mixtures and the differences in $\mathrm{BDE}_{\mathrm{O}-\mathrm{H}}$ with $\mathrm{TOH}$. It is seen that all compounds demonstrated synergism with $\mathrm{TOH}$, only CA manifested additivism with $\mathrm{TOH}$. The strongest inhibiting effects and synergism obtained of the binary mixtures (TBHQ+TOH) and $(\mathrm{BHT}+\mathrm{TOH})$ can be explained by the following mechanisms (Schemes 2\&3). It is seen that both components of the mixture - BHT (or TBHQ) and $\mathrm{TOH}$ can be regenerated during the homo-disproportionation reactions of phenoxyl radicals from BHT (or TBHQ) and TOH formed, as well as during the reactions of crossdisproportionation between their radicals:

Schemes 2, 3 .

\section{Protective effects of binary mixtures of hydroxy-coumarins}

Coumarins are important class of oxygen heterocycles, widespread in plant kingdom (11). They have attracted intense interest recently due to their presence in natural sources, and to their possession of diverse pharmacological properties. 4-Methylcoumarins have been found to possess choleretic, analgesic, antispermatogenic, anti-tubercular and diuretic properties (6). Polyphenolic coumarins are known to act as antioxidants in biological systems, but it is difficult to distinguish their antioxidant activity from the many other effects they produce in cells. In order to study the possible synergism between two phenolic antioxidants, the antioxidant efficiency and reactivity of tree binary mixtures of coumarins and $\mathrm{TOH}\left(\mathrm{Cum}_{1}+\mathrm{TOH}\right.$, $\mathrm{Cum}_{2}+\mathrm{TOH}$ and $\left.\mathrm{Cum}_{3}+\mathrm{TOH}\right)$ were tested and compared. Figure 6 and Table 1 present results obtained. It is found the higher oxidation stability of the lipid substrate in presence of all binary mixtures in comparison with individual compounds.

The synergism was observed only for the binary mixture of 7,8-dihydroxy-4-methyl coumarin $\left(\mathrm{Cum}_{1}\right)$ with $\alpha$-tocopherol $(\mathrm{TOH}) \mathrm{Cum}_{1}+\mathrm{TOH}$ : $\mathrm{IP}_{1+2}(14.2)>\mathrm{IP}_{\mathrm{Cuml} 1}(2.0)+\mathrm{IP}_{\mathrm{TOH}}(10.5)$ and $14 \%$ synergism.

In case of equimolar binary mixture of 6,7dihydroxy-4-methyl-coumarin $\left(\mathrm{Cum}_{2}\right)$ with $\alpha$ tocopherol $(\mathrm{TOH})$, i.e. $\mathrm{Cum}_{2}+\mathrm{TOH}$ it was found an antagonism between two antioxidants:

$\operatorname{IP}_{1+2}(12.7)<\operatorname{IP}_{\mathrm{Cum} 2}(7.1)+\operatorname{IP}_{\mathrm{TOH}}(10.5)$.

In case of 7-hydroxy-4-methyl-coumarin $\left(\mathrm{Cum}_{3}\right)$ with $\alpha$-tocopherol (TOH) $\mathrm{Cum}_{3}+\mathrm{TOH}$ an additivism was observed: $\operatorname{IP}_{1+2}(11.8)=$ $\operatorname{IP}_{\mathrm{Cum} 3}(1.7)+\mathrm{IP}_{\mathrm{TOH}}(10.5)$. 


\section{Regeneration of BHT during homo-dissproponation reaction}<smiles>Cc1cc(C(C)(C)C)c(O)c(C(C)(C)C)c1</smiles>

Butylated Hydroxytoluene (BHT)

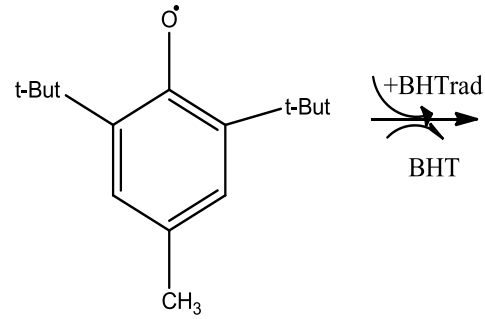

BHT phenoxyl radical<smiles>C=C1C=C(C(C)(C)C)C(=O)C(C(C)(C)C)=C1</smiles>

Tret-Butyl Methylene Quinone

Regeneration of TOH during homo-dissproponation reaction<smiles>Cc1c(C)c2c(c(C)c1O)CCC(C)(P)O2</smiles>

alpha-Tocopherol (TOH)<smiles>Cc1c(C)c2c(c(C)c1[O-])CCC(C)([18OH])O2</smiles>

alpha-Tocopheryl radical ('゚o )<smiles>C=C1C(=O)C(C)=C(C)C2=C1CCC(C)(P)O2</smiles>

Tocopherol Methylene Quinone

Regeneration of TOH and BHT by $\mathrm{H}$ atom transfer reaction -this reaction is reversible<smiles>Cc1c(C)c2c(c(C)c1[O-])CCC(C)([PH3+])O2</smiles>

alpha-Tocopheryl radical (TO )<smiles>Cc1cc(C(C)(C)C)c(O)c(C(C)(C)C)c1</smiles>

BHT<smiles>Cc1c(C)c2c(c(C)c1O)CCC(C)([Pb])O2</smiles>

alpha-Tocopherol (TOH)<smiles>Cc1cc(C(C)(C)C)c([O])c(C(C)(C)C)c1</smiles>

BHT phenoxyl radical

Regeneration of the stronger antioxidant TOH by reaction of cross-dissproportionation<smiles>Cc1c(C)c2c(c(C)c1[O-])CCC(C)([PH2+])O2</smiles>

alpha-Tocopheryl radical (TO)<smiles>Cc1cc(C(C)(C)C)c(Cl)c(C(C)(C)C)c1</smiles>

BHT phenoxyl radical<smiles>C=C1C=C(C(C)(C)C)C(=O)C(C(C)(C)C)=C1</smiles>

alpha-Tocopherol (TOH)
Tret-Butyl Methylene Quinone

Scheme 2. Mechanism of BHT and TOH in binary mixture with possible regeneration of BHT and TOH 
Regeneration of TBHQ during homo-dissproponation reaction

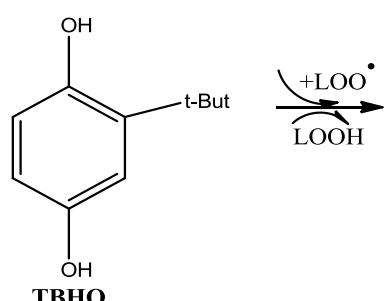

TBHQ

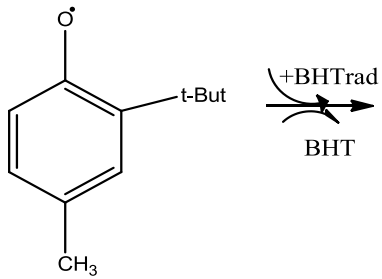

TBHQ semiquinone radical

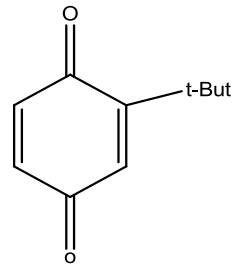

Tret-butyl-para-quinone

Regeneration of TOH during homo-dissproponation reaction<smiles>Cc1c(C)c2c(c(C)c1O)CCC(C)(P)O2</smiles>

alpha-Tocopherol (TOH)

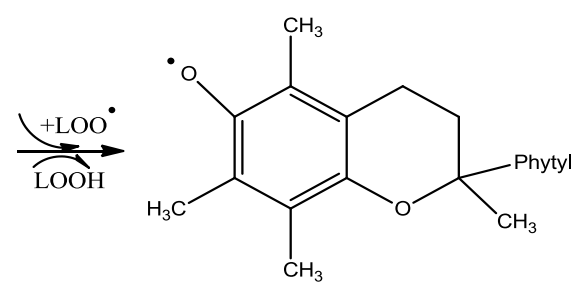

alpha-Tocopheryl radical ( $\dot{0}$ ) )<smiles>C=C1C(=O)C(C)=C(C)C2=C1CCC(C)(P)O2</smiles>

Tocopherol Methylene Quinone

Regeneration of TOH and TBHQ by $\mathrm{H}$ atom transfer reaction -this reaction is reversible<smiles>Cc1c(C)c2c(c(C)c1[O-])CCC(C)(P)O2</smiles>

alpha-Tocopheryl radical (TO )<smiles>CC(C)(C)c1cc(O)ccc1Cl</smiles>

$\checkmark$ TBHQ semiquinone radical<smiles>Cc1c(C)c2c(c(C)c1O)CCC(C)(P)O2</smiles>

alpha-Tocopherol (TOH)<smiles>CC(C)(C)c1cc(O)ccc1O</smiles>

TBHQ<smiles>Cc1c(C)c2c(c(C)c1O)CCC(C)(P)O2</smiles>

alpha-Tocopherol (TOH)<smiles>CC(C)(C)c1cc(O)ccc1Cl</smiles>

TBHQ semiquinone radical<smiles>Cc1c(C)c2c(c(C)c1[O-])CCC(C)([Pb])O2</smiles>

Regeneration of TOH and TBHQ by reactionof cross-dissproportionation

Scheme 3. Mechanism of TBHQ and TOH in binary mixture with possible regeneration of TBHQ and TOH

Tables 2 and 3 present the differences in $\mathrm{BDE}_{\mathrm{O}-}$ H with $\mathrm{TOH}$. 
Table 2. Binary mixtures of bi-phenolic and polyphenolic antioxidants with TOH

\begin{tabular}{|c|c|c|c|c|c|}
\hline$Q(\mathrm{OH})_{2}$ & $Q(\mathrm{OH})_{2}+\mathrm{TOH}$ & $\begin{array}{l}B D E_{Q H 2} \\
\triangle B D E_{O-H}\end{array}$ & $\begin{array}{l}\mathrm{QH}_{2} \quad \text { rege- } \\
\text { neration }\end{array}$ & TOH regeneration & Side reactions \\
\hline $\mathrm{CA}$ & Additivism & $\begin{array}{l}=\mathrm{BDE}_{\mathrm{TOH}} \\
\Delta \mathrm{BDE}=0\end{array}$ & yes & $\begin{array}{l}\mathrm{H} \text { atom transfer } \\
\text { Cross-disproport }\end{array}$ & No \\
\hline $\begin{array}{l}\text { 7,8-di-OHCum } \\
\mathrm{Cum}_{1}(\mathrm{OH})_{2}\end{array}$ & Synergism & $\begin{array}{l}\uparrow_{\mathrm{BDE}}^{\mathrm{Tон}} \\
\Delta \mathrm{BDE}^{>} 0\end{array}$ & yes & $\begin{array}{l}\mathrm{H} \text { atom transfer } \\
\text { Cross-disproport }\end{array}$ & No \\
\hline $\begin{array}{l}\text { 6,7-di-OHCum } \\
\mathrm{Cum}_{2}(\mathrm{OH})_{2}\end{array}$ & Antagonism & $\begin{array}{l}\downarrow \mathrm{BDE}_{\text {тон }} \\
\Delta \mathrm{BDE}<0\end{array}$ & yes & $\mathrm{H}$ atom transfer & Cross-recombination \\
\hline FLAVONOI & & & & & \\
\hline $\mathrm{Qu}+\mathrm{Lu}$ & Antagonism & $\mathrm{BDE}<0$ & yes & - & Cross-recombination \\
\hline $\mathrm{Qu}+\mathrm{Ru}$ & Antagonism & $\mathrm{BDE}<0$ & yes & - & Cross-recombination \\
\hline $\mathrm{Qu}+\mathrm{TOH}$ & $\begin{array}{l}\text { Synergism } \\
46 \%\end{array}$ & $\begin{array}{l}\uparrow \mathrm{BDE}_{\mathrm{TоH}} \\
\mathrm{BDE}>0\end{array}$ & yes & $\begin{array}{l}\mathrm{H} \text { atom transfer } \\
\text { Cross-disproport }\end{array}$ & No \\
\hline $\mathrm{Lu}+\mathrm{TOH}$ & $\begin{array}{l}\text { Synergism } \\
19 \%\end{array}$ & $\begin{array}{l}\uparrow \mathrm{BDE}_{\text {тон }} \\
\mathrm{BDE}>0\end{array}$ & yes & $\begin{array}{l}\mathrm{H} \text { atom transfer } \\
\text { Cross-disproport }\end{array}$ & No \\
\hline $\mathrm{Ru}+\mathrm{TOH}$ & $\begin{array}{l}\text { Synergism } \\
89 \%\end{array}$ & $\begin{array}{l}\uparrow \mathrm{BDE}_{\text {тон }} \\
\mathrm{BDE}^{>} 0\end{array}$ & yes & $\begin{array}{l}\mathrm{H} \text { atom transfer } \\
\text { Cross-disproport }\end{array}$ & No \\
\hline
\end{tabular}

Table 3. Binary mixtures of monophenolic antioxidants $A H$ with TOH

\begin{tabular}{|c|c|c|c|c|c|}
\hline $\boldsymbol{A H}$ & $A H+T O H$ & $B D E_{A-H}$ & AH regener. & TOH regeneration & Side reactions \\
\hline \multirow[t]{2}{*}{$\overline{\mathrm{BHT}}$} & \multirow[t]{2}{*}{ Synergism } & $\uparrow \mathrm{BDE}_{\text {тон }}$ & \multirow[t]{2}{*}{ yes } & $\mathrm{H}$ atom tansfer, & No t-But \\
\hline & & $\Delta \mathrm{BDE}>0$ & & cross-dispropor. & \\
\hline \multirow[t]{2}{*}{ SA } & \multirow[t]{2}{*}{ Synergism } & $\uparrow \mathrm{BDE}_{\text {тон }}$ & \multirow[t]{2}{*}{ no } & \multirow[t]{2}{*}{$\mathrm{H}$ atom transfer } & \multirow[t]{2}{*}{ Yes + } \\
\hline & & $\Delta \mathrm{BDE}>0$ & & & \\
\hline \multirow[t]{2}{*}{ FA } & \multirow[t]{2}{*}{ Synergism } & $\uparrow \mathrm{BDE}_{\mathrm{TOH}}$ & \multirow[t]{2}{*}{ no } & \multirow[t]{2}{*}{$\mathrm{H}$ atom transfer } & \multirow[t]{2}{*}{ Yes + } \\
\hline & & $\Delta \mathrm{BDE}>0$ & & & \\
\hline \multirow[t]{2}{*}{$\mathrm{M}_{1} \mathrm{OH}$} & \multirow[t]{2}{*}{ Synergism } & $\overline{p B D E}_{\text {тон }}$ & \multirow[t]{2}{*}{ no } & \multirow[t]{2}{*}{$\mathrm{H}$ atom transfer } & \multirow[t]{2}{*}{ Yes +} \\
\hline & & $\Delta \mathrm{BDE}>0$ & & & \\
\hline \multirow[t]{2}{*}{$\mathrm{M}_{2} \mathrm{OH}$} & \multirow[t]{2}{*}{ Antagonism } & $\uparrow \mathrm{BDE}_{\text {тон }}$ & \multirow[t]{2}{*}{ no } & \multirow[t]{2}{*}{$\mathrm{H}$ atom transfer } & \multirow[t]{2}{*}{ Yes +++ } \\
\hline & & $\Delta \mathrm{BDE}>0$ & & & \\
\hline \multirow{2}{*}{$\begin{array}{l}\text { 7-OH-Cum } \\
\mathrm{Cum}_{3} \mathrm{OH}\end{array}$} & \multirow[t]{2}{*}{ Additivism } & $\uparrow \mathrm{BDE}_{\mathrm{TOH}}$ & \multirow[t]{2}{*}{ no } & \multirow[t]{2}{*}{$\mathrm{H}$ atom transfer } & \multirow[t]{2}{*}{ Yes +++ } \\
\hline & & $\Delta \mathrm{BDE}>0$ & & & \\
\hline
\end{tabular}




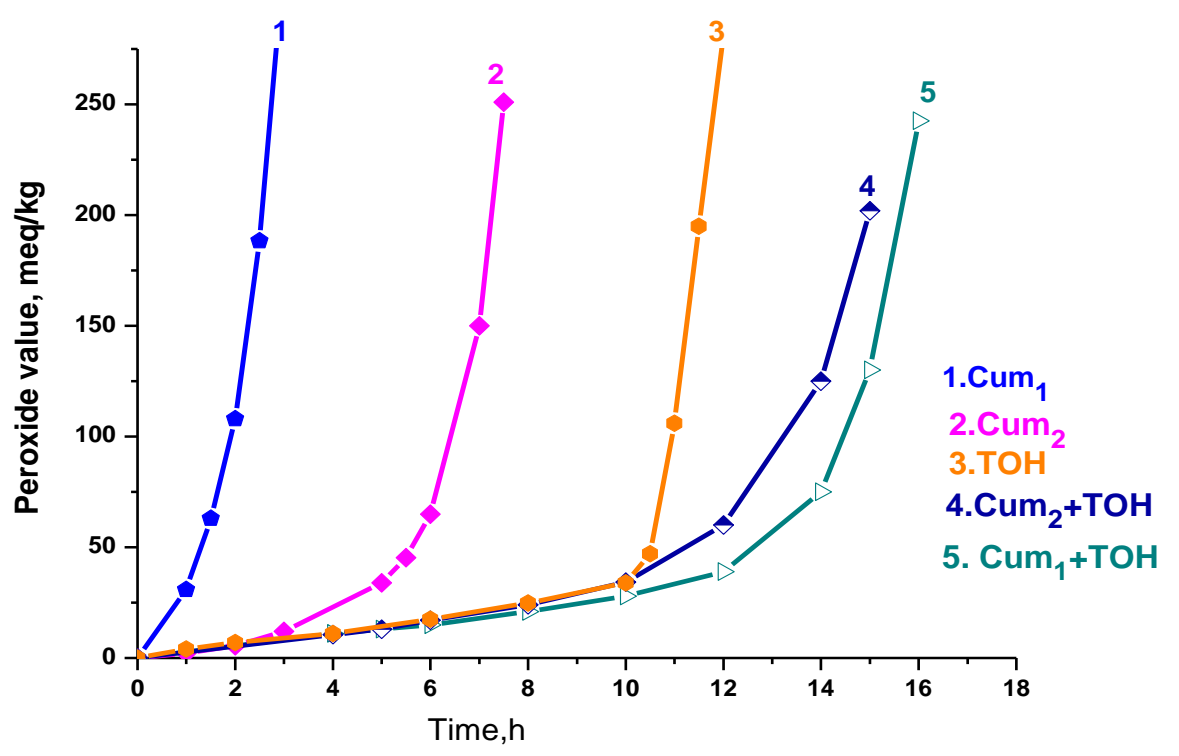

Figure 6. Kinetic curves of lipid hydroperoxides accumulation during TGSO autoxidation at $80^{\circ} \mathrm{C}$ in presence of $0.1 \mathrm{mM}$ 7,8-dihydroxy-4-methyl-coumarin $\left(\mathrm{Cum}_{1}\right), 6,7$-dihydroxy-4-methyl-coumarin $\left(\mathrm{Cum}_{2}\right), \alpha$-tocopherol $(\mathrm{TOH})$ and of their equimolar $(1: 1)$ binary mixtures $\left(\mathrm{Cum}_{1}+\mathrm{TOH}\right)$ and $\left(\mathrm{Cum}_{2}+\mathrm{TOH}\right)$

The highest oxidation stability of TGSO in presence of all binary mixtures with $\alpha$ tocopherol (TOH) may be explained taking into account that the both antioxidants may be regenerated during the oxidation process. It is known that the catecholic moiety of the coumarine molecules allows formation of semiquinone radicals. These semiquinone radicals may regenerate the initial antioxidant molecule during reaction of bimolecular recombination with homo- and crossdisproportionation of semiquinone radicals:

\section{Scheme 4.}

These reactions demonstrate that during lipid oxidation process initial molecules of 7,8dihydroxy-4-methyl coumarin, $\mathrm{Cum}_{1}(\mathrm{OH})_{2}$ and $\mathrm{TOH}$ are regenerated by different mechanisms and that makes this binary mixture the most powerful antioxidant compositions. It could be seen that the positions of both phenolic groups in coumarin molecule plays an important role in their mechanism of action. In case of 7-hydrpxy-4methyl- coumarin, $\mathrm{Cum}_{3} \mathrm{OH}$, the observed additivism of the binary mixture $\left(\mathrm{Cum}_{3}+\mathrm{TOH}\right)$ may be explained with the possible reactions of homo-disproportionation of $\mathrm{TO} \cdot$ and cross-disproportionation of phenoxyl radical $\left(\mathrm{Cum}_{3} \mathrm{O} \bullet\right)$ from monohydroxy coumarin, and tocopheryl radical $(\mathrm{TO} \bullet)$ with regeneration of $\mathrm{TOH}$.

Considering that 4-methylcoumarins, in contrast to many other coumarins, are not metabolized to toxic epoxide intermediates, these results indicate the possible application of these compounds as individual antioxidants and/or in complex binary mixtures.

\section{Protective effects of monomers and dimers}

Dehydrozingerone $\left(\mathrm{M}_{1} \mathrm{OH}\right)$ is a half molecule of curcumin - one of the most powerful antioxidant with a wide spectrum of its biological activity (12). Ginger and curcumin are the well-known spices. Recently synthesized natural-like C2symmetry hydroxylated biphenyls (dimers) of their corresponding monomers (dehydrozingerone, $\mathrm{M}_{1} \mathrm{OH}$, zingerone, $\mathrm{M}_{2} \mathrm{OH}$ and ferulic acid, FA) were selected for this study, because of their interesting biological activity against to neuro-degenerative diseases and melanoma cancer (7).

It is seen (Figure 7, Table 1) that dimer of dehydrozingerone, $\mathrm{D}_{1}(\mathrm{OH})_{2}$ is able to ensure the higher oxidation stability of lipid substrate, i.e. it has the better protective effect in comparison with corresponding monomer $\left(\mathrm{M}_{1} \mathrm{OH}\right)$. TOH manifested the best protective effect on lipid autoxidation in comparison with other individual compounds. However, it is evident that AscPH didn't show any antioxidant activity (potential). 
Regeneration of dihydroxy-coumarin $\mathrm{Cum}_{1}(\mathrm{OH})_{2}$ by cross-disproportionation reaction<smiles>Cc1cc(=O)oc2c(O)c(O)ccc12</smiles>

$\mathrm{Cum}_{1}(\mathrm{OH})_{2}$<smiles>Cc1cc(=O)oc2c(O)c(O)ccc12</smiles>

$\mathrm{Cum}_{1}(\mathrm{OH}) \mathbf{O}$$$
\text { Coumarin semiquino }
$$

Coumarin semiquinone radical

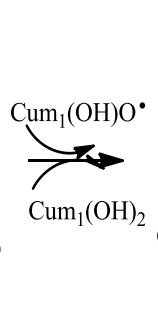<smiles>Cc1cc(=O)oc2c1C=CC(=O)C2=O</smiles>

$\mathrm{Cum}_{1}(\mathbf{O})_{2}$ Coumarin ortho quinone<smiles>Cc1c(O)c(C)c2c(c1O)C=CC(C)(P)O2</smiles><smiles>Cc1c(C)c([O])c2c(c1C)C=CC(C)([18O])O2</smiles><smiles>C=C1C(=O)C(C)=C(C)C2=C1C=CC(C)(P)O2</smiles>

$\mathrm{Cum}_{1}(\mathrm{OH})_{2}$

Tocopheryl methylene quinon

Regeneration of $\mathrm{Cum}_{1}(\mathrm{OH})_{2}$ by $\mathrm{H}$ atom transfer and cross-disproportionation reactions<smiles>Cc1cc(=O)oc2c(O)c(O)ccc12</smiles>

$\mathrm{Cum}_{1}(\mathrm{OH}) \mathrm{O}$ Coumarin semiquinone radical<smiles>Cc1c(C)c2c(c(C)c1[O-])C=CC(C)([18O])O2</smiles>

TO<smiles>Cc1cc(=O)oc2c1C=CC(=O)C2=O</smiles>

Regeneration of TOH by cross-disproportionation reactions and $\mathrm{H}$ atom transfer<smiles>Cc1c(C)c2c(c(C)c1[O-])OC(C)([18O])C=C2</smiles><smiles>[CH2+]C1([18OH])C=Cc2c(C)c(C)c(O)c(C)c2O1</smiles>

Coumarin semiquinone radical

Scheme 4. Mechanism of synergistic effect of binary mixture of 7,8-dihydroxy-4-methyl-coumarin, $\mathrm{Cum}{ }_{1}(\mathrm{OH})_{2}$ with $\alpha$ - tocopherol (TOH) 


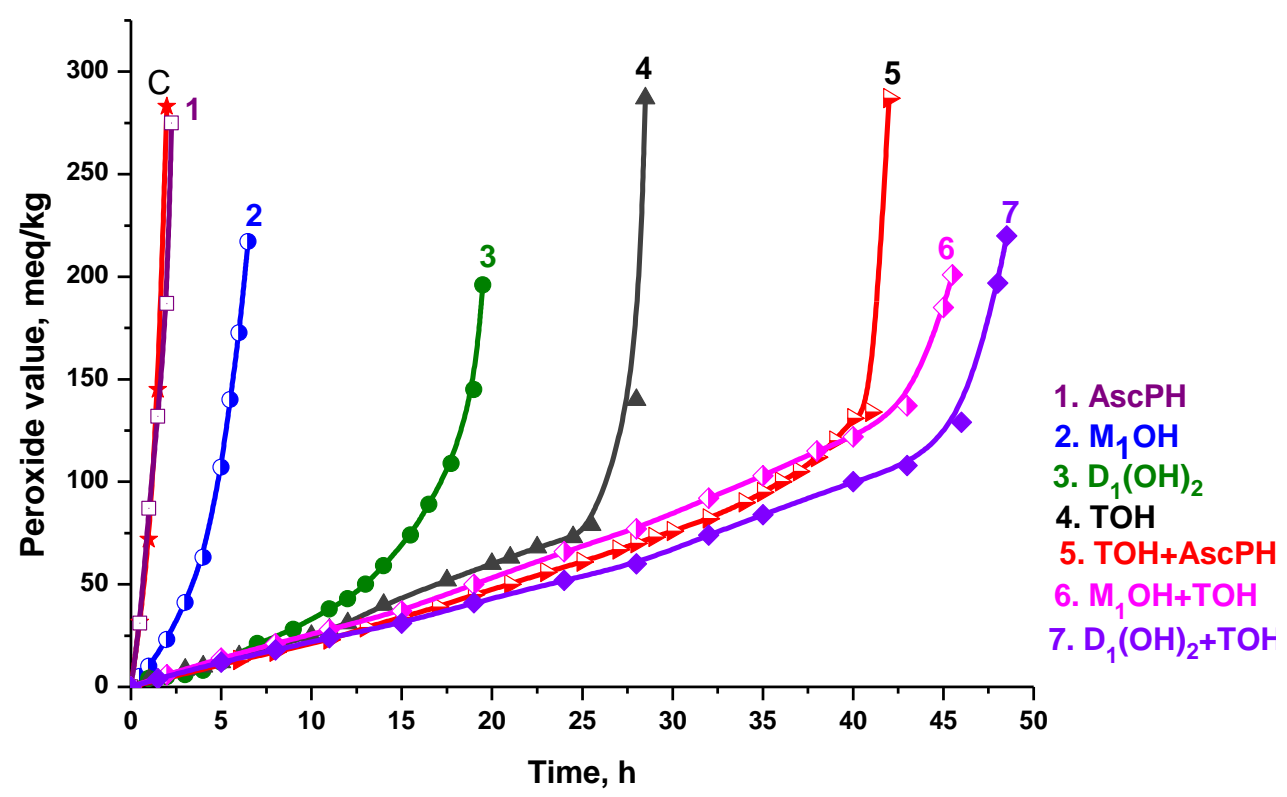

Figure 7. Kinetic curves of lipid hydroperoxides accumulation during TGSO autoxidation at $80^{\circ} \mathrm{C}$ in absence (control, $\mathrm{C}$ ) and in presence of $0.1 \mathrm{mM}$ monomer $\mathrm{M}_{1} \mathrm{OH}$ (dehydrozingerone), of dimer of dehydrozingerone $\left[\mathrm{D}_{1}(\mathrm{OH})_{2}\right]$, ascorbyl palmitate $(\mathrm{AscPH}), \alpha$-tocopherol $(\mathrm{TOH})$ and their equimolar binary mixtures $\left(\mathrm{M}_{1} \mathrm{OH}+\mathrm{TOH}\right)$, $\left.\left[\mathrm{D}_{1}(\mathrm{OH})_{2}+\mathrm{TOH}\right)\right]$ and $(\mathrm{TOH}+\mathrm{AscPH})$.

The kinetic curve in presence of AscPH is the same as for the control sample. New orders of antioxidant efficiency (as protection factor, PF) and antioxidant reactivity (as inhibition degree, ID) were found for the individual compounds:

PF: $\mathrm{TOH}(21.2)>\mathrm{D}_{1}(\mathrm{OH})_{2} \quad(13.5)>\mathrm{M}_{1} \mathrm{OH}$ (3.5) $>$ AscPH (1.0)

ID: TOH (29.3) $=\mathrm{D}_{1}(\mathrm{OH})_{2} \quad(29.3)>\mathrm{M}_{1} \mathrm{OH}$ (6.3) > AscPH (1.0)

The observed lower antioxidant activity of $\mathrm{M}_{1} \mathrm{OH}$ and $\mathrm{D}_{1}(\mathrm{OH})_{2}$ respect to $\mathrm{TOH}$ is expected as a result of the higher bond dissociation enthalpy (BDE) of $\mathrm{OH}$ groups of $\mathrm{M}_{1} \mathrm{OH}$ and $\mathrm{D}_{1}(\mathrm{OH})_{2}$ in comparison with those of $\mathrm{TOH}$ $\left(\Delta \mathrm{BDE}_{\mathrm{M} 1 \mathrm{OH}}=9.6\right.$ and $\Delta \mathrm{BDE}_{\mathrm{D} 1(\mathrm{OH}) 2}=9.0 \mathrm{kcal} / \mathrm{mol}$, respectively) (7). Another reason for the lower antioxidant activity of $\mathrm{M}_{1} \mathrm{OH}$ and $\mathrm{D}_{1}(\mathrm{OH})_{2}$ with respect to $\mathrm{TOH}$ can be explain with no possibility of their phenoxyl radicals to be regenerated like $\mathrm{TOH}$ during homodisproportionation reaction.

Data obtained (Figure 7 and Table 1) showed that both binary mixtures $\left(\mathrm{M}_{1} \mathrm{OH}+\mathrm{TOH}\right.$ and $\left.\mathrm{D}_{1}(\mathrm{OH})_{2}+\mathrm{TOH}\right)$ lead to the maximal oxidation stability of lipid substrate in comparison with the corresponding individual components. The latest is of importance for the practice, because these binary mixtures are able to ensure the best protective effect on the lipid substrate being oxidized.

PF: $\mathrm{D}_{1}(\mathrm{OH})_{2}+\mathrm{TOH}(35.4)>\mathrm{M}_{1} \mathrm{OH}+\mathrm{TOH}(32.7)>$ $\mathrm{TOH}(21.2)>\mathrm{D}_{1}(\mathrm{OH})_{2}(13.5)>>\mathrm{M}_{1} \mathrm{OH}(3.5)$ ID: $\mathrm{D}_{1}(\mathrm{OH})_{2}+\mathrm{TOH}(29.3)=\mathrm{TOH}(29.3)=$ $\mathrm{D}_{1}(\mathrm{OH})_{2}(29.3)>\mathrm{M}_{1} \mathrm{OH}+\mathrm{TOH}(25.9)>\mathrm{M}_{1} \mathrm{OH}$ (6.3) 


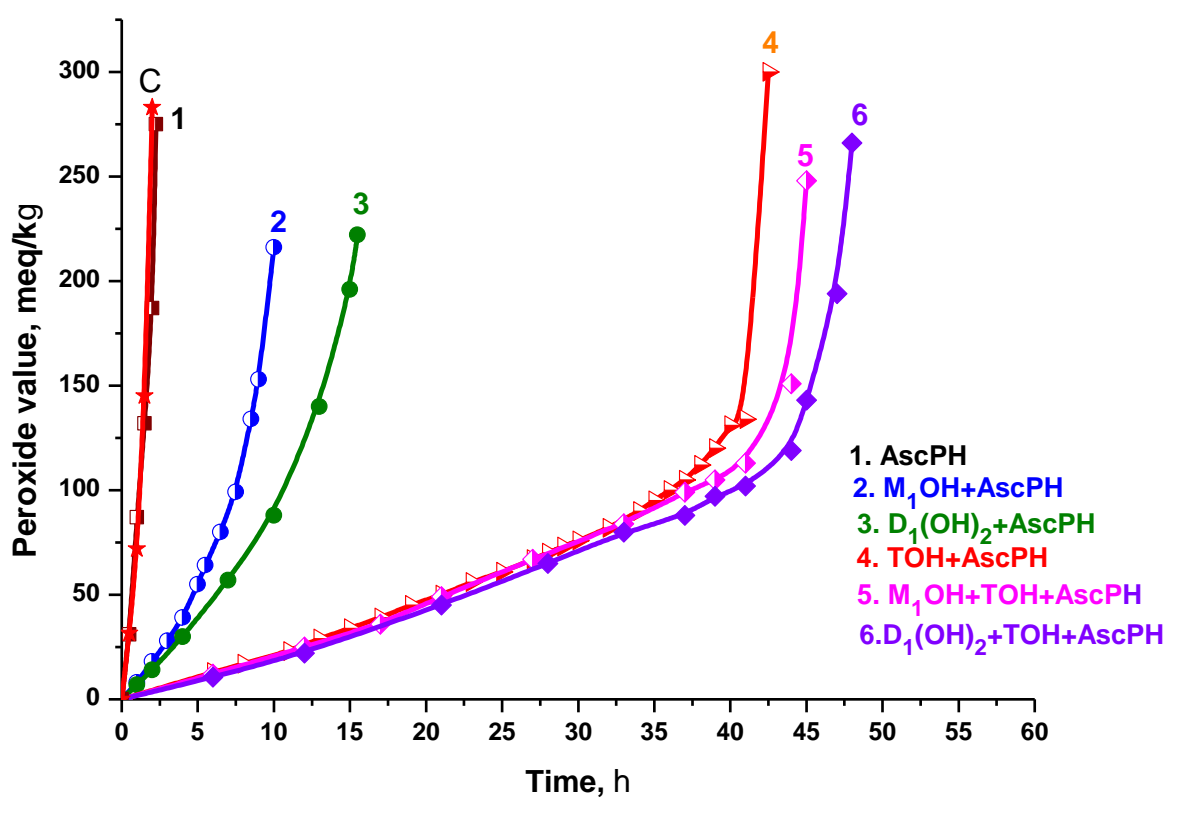

Figure 8. Kinetic curves of lipid hydroperoxides accumulation during TGSO autoxidation at $80^{\circ} \mathrm{C}$ in absence (control, C) and in presence of $0.1 \mathrm{mM}$ ascorbyl palmitate $(\mathrm{AscPH})$, of equimolar (1:1) binary mixtures with AscPH of monomer $\mathrm{M}_{1} \mathrm{OH}+\mathrm{AscPH}$ and of dimer $\mathrm{D}_{1}(\mathrm{OH})_{2}+\mathrm{AscPH}$, and of their triple (1:1:1) equimolar mixtures with $\mathrm{TOH}$ and $\mathrm{AscPH}$ of monomer $\left.\mathrm{M}_{1} \mathrm{OH}+\mathrm{TOH}+\mathrm{Asc} \mathrm{PH}\right)$ and of dimer $\left.\mathrm{D}_{1}(\mathrm{OH})_{2}+\mathrm{TOH}+\mathrm{AscPH}\right)$.

Effect of equimolar (1:1) binary mixtures of studied compounds with ascorbyl palmitate (AscPH)

Figure 8 and Table 1 showed the data observed for the equimolar binary mixtures of $\mathrm{M}_{1} \mathrm{OH}$, $\mathrm{D}_{1}(\mathrm{OH})_{2}$ and TOH with AscPH. New orders of antioxidant properties were obtained:

PF: TOH+AscPH (31.5) >> $\mathrm{D}_{1}(\mathrm{OH})_{2}+\mathrm{AscPH}$ (10.4) $>\mathrm{M}_{1} \mathrm{OH}+\mathrm{AscPH}$ (6.2) $>$ AscPH (1.0)

ID: $\mathrm{TOH}+\mathrm{AscPH}(29.3)>\mathrm{D}_{1}(\mathrm{OH})_{2}+\mathrm{AscPH}$ (8.8) $>\mathrm{M}_{1} \mathrm{OH}+\mathrm{Asc} \mathrm{PH}$ (6.8) $>\mathrm{Asc} \mathrm{PH}$ (1.0)

The highest antioxidant efficiency (PF) was found for binary mixture of $\mathrm{TOH}+\mathrm{AscPH}$, which is 3-fold higher than that of $\mathrm{D}_{1}(\mathrm{OH})_{2}+\mathrm{Asc} \mathrm{PH}$ and 5-fold higher than that of $\mathrm{M}_{1} \mathrm{OH}+\mathrm{AscPH} . \mathrm{D}_{1}(\mathrm{OH})_{2}$ in binary mixture with AscPH leads to the higher oxidation stability of lipid substrate than in case of $\mathrm{M}_{1} \mathrm{OH}+\mathrm{AscPH}$.

The binary mixtures of studied compounds $\left(\mathrm{M}_{1} \mathrm{OH}+\mathrm{Asc} \mathrm{PH}\right.$ and $\left.\mathrm{D}_{1}(\mathrm{OH})_{2}+\mathrm{AscPH}\right)$ showed higher protective effect than of AscPH. The latest due to the possible regeneration of $\mathrm{M}_{1} \mathrm{OH}$ and $\mathrm{D}_{1}(\mathrm{OH})_{2}$ from AscPH during the oxidation process:

$\mathrm{M}_{1} \mathrm{O} \bullet+A s c \mathrm{PH} \rightarrow \mathrm{M}_{1} \mathrm{OH}+\mathrm{AscP} \bullet$ reaction of $\mathrm{H}$ atom transfer with monomer regeneration

$\mathrm{M}_{1} \mathrm{O} \bullet+\mathrm{AscP} \bullet \rightarrow \mathrm{M}_{1} \mathrm{OH}+$ DHAP $($ DHAP, dehydroascorbyl palmitate) cross disproportionation reaction with monomer regeneration.

Both reactions with monomer regeneration are of importance for the synergism of $\mathrm{M}_{1} \mathrm{OH}+\mathrm{AscPH}$ mixture obtained, because $\mathrm{M}_{1} \mathrm{OH}$ is the stronger antioxidant in comparison with AscPH. Our results confirm again $\mathrm{AscPH}$ as synergist, but not as antioxidant during bulk lipid autoxidation. Antagonism was detected only for $\mathrm{D}_{1}(\mathrm{OH})_{2}$ + AscPH binary mixture that evidenced the lower level of dimer regeneration from AscPH. This result can be explained with the reverse character of $\mathrm{H}$ atom transfer reactions:

$$
\mathrm{D}_{1}(\mathrm{OH}) \mathrm{O} \bullet+\mathrm{AscPH} \Leftrightarrow \mathrm{D}_{1}(\mathrm{OH})_{2}+\mathrm{AscP} \bullet
$$

Probably it is a result of the possible AscPH regeneration in reaction between AscP• and $\mathrm{D}_{1}(\mathrm{OH})_{2}$ and thus reduces its activity.

Another reason for antagonism obtained is the possible cross recombination reaction between AscP• and $\mathrm{D}_{1}(\mathrm{OH}) \mathrm{O} \cdot$ to inactive product. The latest reduced the concentration of dimer phenoxyl radical which could be regenerated by $\mathrm{H}$ atom transfer from $\mathrm{AscPH}$.

We expected to increase significantly the efficiency of antioxidant compositions, due to the regeneration by different reactions of $\mathrm{TOH}$ and $\mathrm{M}_{1} \mathrm{OH}$ /or $\mathrm{D}_{1}(\mathrm{OH})_{2}$ during the oxidative process by preparing ternary mixtures 
$\mathrm{M}_{1} \mathrm{OH}+\mathrm{TOH}+\mathrm{AscPH} \quad$ and $\quad \mathrm{D}_{1}(\mathrm{OH})_{2}+\mathrm{TOH}+$ AscPH. The protective action of triple mixtures of $\mathrm{M}_{1} \mathrm{OH}$ and $\mathrm{D}_{1}(\mathrm{OH})_{2}$ with $\mathrm{TOH}$ and $\mathrm{AscPH}$ is presented at Figure 8 and Table 4.

PF: $\mathrm{D}_{1}(\mathrm{OH})_{2}+\mathrm{TOH}+\mathrm{AscPH}(35.4)>\mathrm{M}_{1} \mathrm{OH}$ $+\mathrm{TOH}+\mathrm{AscPH}(33.1)$

ID: $\mathrm{D}_{1}(\mathrm{OH})_{2}+\mathrm{TOH}+\mathrm{AscPH}(35.2)>\mathrm{M}_{1} \mathrm{OH}+$ $\mathrm{TOH}+\mathrm{AscPH}$ (29.3)

Triple mixture of $\mathrm{D}_{1}(\mathrm{OH})_{2}$ with $\mathrm{TOH}$ and AscPH manifested also a higher antioxidant efficiency and reactivity than the corresponding triple mixture of $\mathrm{M}_{1} \mathrm{OH}$. However, triple mixture of $\mathrm{M}_{1} \mathrm{OH}+\mathrm{TOH}+\mathrm{AscPH}$ showed similar $\mathrm{PF}$ as for double mixture of $\mathrm{M}_{1} \mathrm{OH}+\mathrm{AscPH}$.
PF: $\mathrm{M}_{1} \mathrm{OH}+\mathrm{TOH}+\mathrm{Asc} \mathrm{PH}(33.1)>\mathrm{M}_{1} \mathrm{OH}+\mathrm{TOH}$ (32.7) > $\mathrm{TOH}(21.2)>>\mathrm{M}_{1} \mathrm{OH}+\mathrm{AscPH}(6.2)>$ $\mathrm{M}_{1} \mathrm{OH}(3.5)$

PF: $\mathrm{D}_{1}(\mathrm{OH})_{2}+\mathrm{TOH}+\mathrm{AscPH}(35.4)=\mathrm{D}_{1}(\mathrm{OH})_{2}+$ $\mathrm{TOH}(35.4)>>\mathrm{D}_{1}(\mathrm{OH})_{2}(13.5)>\mathrm{D}_{1}(\mathrm{OH})_{2}+\mathrm{Asc} \mathrm{PH}$ (10.4)

We proved by HPLC monitoring of the TOH content during the process of lipid autoxidation (9) that the mechanism of synergistic action of binary and triple mixtures of $\mathrm{M}_{1} \mathrm{OH}$ and $\mathrm{D}_{1}(\mathrm{OH})_{2}$ with $\mathrm{TOH}$ and $\mathrm{AscPH}$ is due to the regeneration of TOH (Table 4).

Table 4. Lipid hydroperoxides concentration [LOOH] and $\alpha$-tocopherol (TOH) content determined during lipid autoxidation of triglycerides of sunflower oil (TGSO) at $80^{\circ} \mathrm{C}$.

\begin{tabular}{|c|c|c|c|}
\hline Abbrev. of mixtures & $\begin{array}{c}\text { Time, } \\
h\end{array}$ & $\begin{array}{c}{[\mathrm{LOOH}] \text { average, }} \\
\mathrm{mM}\end{array}$ & $\begin{array}{c}\text { TOH content, } \\
\mathrm{mg} / \mathrm{g}\end{array}$ \\
\hline$(\mathrm{TOH})_{5}$ & 5 & $4.9 \pm 1.1$ & $0.458 \pm 0.018$ \\
\hline$(\mathrm{TOH})_{10}$ & 10 & $11.8 \pm 1.2$ & $0.452 \pm 0.018$ \\
\hline$(\mathrm{TOH})_{15}$ & 15 & $18.0 \pm 2.0$ & $0.451 \pm 0.018$ \\
\hline$(\mathrm{TOH})_{20}$ & 20 & $25.2 \pm 4.3$ & $0.380 \pm 0.015$ \\
\hline$(\mathrm{TOH})_{25}$ & 25 & $33.5 \pm 5.5$ & $0.258 \pm 0.010$ \\
\hline$(\mathrm{TOH})_{30}$ & 30 & $143.0 \pm 5.0$ & $0.016 \pm 0.001$ \\
\hline Equimolar binary mixtures & with & AscPH & \\
\hline$(\mathrm{TOH}+\mathrm{AscPH})_{5}$ & 5 & $2.7 \pm 2.5$ & $0.466 \pm 0.019$ \\
\hline$(\mathrm{TOH}+\mathrm{AscPH})_{10}$ & 10 & $5.4 \pm 4.6$ & $0.454 \pm 0.018$ \\
\hline$(\mathrm{TOH}+\mathrm{AscPH})_{15}$ & 15 & $10.2 \pm 6.4$ & $0.445 \pm 0.018$ \\
\hline$(\mathrm{TOH}+\mathrm{AscPH})_{20}$ & 20 & $14.7 \pm 8.8$ & $0.442 \pm 0.018$ \\
\hline$(\mathrm{TOH}+\mathrm{AscPH})_{30}$ & 30 & $28.0 \pm 12.0$ & $0.440 \pm 0.018$ \\
\hline$(\mathrm{TOH}+\mathrm{AscPH})_{45}$ & 45 & $152.0 \pm 3.0$ & $0.059 \pm 0.002$ \\
\hline Equimolar binary mixtures & with & $\mathrm{TOH}$ & \\
\hline$\left(\mathrm{M}_{1} \mathrm{OH}+\mathrm{TOH}\right)_{5}$ & 5 & $6.3 \pm 1.5$ & $0.466 \pm 0.019$ \\
\hline$\left(\mathrm{M}_{1} \mathrm{OH}+\mathrm{TOH}\right)_{10}$ & 10 & $11.0 \pm 2.0$ & $0.449 \pm 0.018$ \\
\hline$\left(\mathrm{M}_{1} \mathrm{OH}+\mathrm{TOH}\right)_{15}$ & 15 & $16.2 \pm 1.8$ & $0.442 \pm 0.018$ \\
\hline$\left(\mathrm{M}_{1} \mathrm{OH}+\mathrm{TOH}\right)_{20}$ & 20 & $21.6 \pm 2.3$ & $0.366 \pm 0.015$ \\
\hline$\left(\mathrm{M}_{1} \mathrm{OH}+\mathrm{TOH}\right)_{30}$ & 30 & $39.2 \pm 1.2$ & $0.288 \pm 0.012$ \\
\hline$\left(\mathrm{M}_{1} \mathrm{OH}+\mathrm{TOH}\right)_{45}$ & 45 & $86.0 \pm 20.0$ & $0.047 \pm 0.002$ \\
\hline$\left(\mathrm{D}_{1}(\mathrm{OH})_{2}+\mathrm{TOH}\right)_{5}$ & 5 & $5.7 \pm 0.9$ & $0.462 \pm 0.018$ \\
\hline$\left(\mathrm{D}_{1}(\mathrm{OH})_{2}+\mathrm{TOH}\right)_{10}$ & 10 & $11.3 \pm 1.3$ & $0.459 \pm 0.018$ \\
\hline$\left(\mathrm{D}_{1}(\mathrm{OH})_{2}+\mathrm{TOH}\right)_{15}$ & 15 & $15.7 \pm 2.6$ & $0.452 \pm 0.018$ \\
\hline$\left(\mathrm{D}_{1}(\mathrm{OH})_{2}+\mathrm{TOH}\right)_{20}$ & 20 & $23.0 \pm 1.0$ & $0.396 \pm 0.016$ \\
\hline$\left(\mathrm{D}_{1}(\mathrm{OH})_{2}+\mathrm{TOH}\right)_{30}$ & 30 & $39.4 \pm 4.5$ & $0.296 \pm 0.012$ \\
\hline$\left(\mathrm{D}_{1}(\mathrm{OH})_{2}+\mathrm{TOH}\right)_{45}$ & 45 & $64.7 \pm 2.3$ & $0.049 \pm 0.002$ \\
\hline Equimolar triple mixtures & with & TOH and AscPH & \\
\hline$\left(\mathrm{M}_{1} \mathrm{OH}+\mathrm{TOH}+\mathrm{AscPH}\right)_{5}$ & 5 & $2.0 \pm 2.0$ & $0.468 \pm 0.019$ \\
\hline$\left(\mathrm{M}_{1} \mathrm{OH}+\mathrm{TOH}+\mathrm{AscPH}\right)_{10}$ & 10 & $4.8 \pm 4.8$ & $0.467 \pm 0.019$ \\
\hline$\left(\mathrm{M}_{1} \mathrm{OH}+\mathrm{TOH}+\mathrm{AscPH}\right)_{15}$ & 15 & $9.5 \pm 9.5$ & $0.458 \pm 0.018$ \\
\hline$\left(\mathrm{M}_{1} \mathrm{OH}+\mathrm{TOH}+\mathrm{AscPH}\right)_{20}$ & 20 & $13.0 \pm 7.0$ & $0.449 \pm 0.018$ \\
\hline$\left(\mathrm{M}_{1} \mathrm{OH}+\mathrm{TOH}+\mathrm{AscPH}\right)_{30}$ & 30 & $28.0 \pm 7.0$ & $0.329 \pm 0.013$ \\
\hline$\left(\mathrm{M}_{1} \mathrm{OH}+\mathrm{TOH}+\mathrm{AscPH}\right)_{45}$ & 45 & $91.0 \pm 33.0$ & $0.114 \pm 0.005$ \\
\hline$\left(\mathrm{D}_{1}(\mathrm{OH})_{2}+\mathrm{TOH}+\mathrm{AscPH}\right)_{5}$ & 5 & $2.0 \pm 2.0$ & $0.468 \pm 0.019$ \\
\hline$\left(\mathrm{D}_{1}(\mathrm{OH})_{2}+\mathrm{TOH}+\mathrm{AscPH}\right)_{10}$ & 10 & $4.8 \pm 4.8$ & $0.466 \pm 0.019$ \\
\hline$\left(\mathrm{D}_{1}(\mathrm{OH})_{2}+\mathrm{TOH}+\mathrm{AscPH}\right)_{15}$ & 15 & $8.5 \pm 4.5$ & $0.462 \pm 0.018$ \\
\hline$\left(\mathrm{D}_{1}(\mathrm{OH})_{2}+\mathrm{TOH}+\mathrm{AscPH}\right)_{20}$ & 20 & $12.3 \pm 6.8$ & $0.459 \pm 0.018$ \\
\hline$\left(\mathrm{D}_{1}(\mathrm{OH})_{2}+\mathrm{TOH}+\mathrm{AscPH}\right)_{30}$ & 30 & $24.0 \pm 10.0$ & $0.426 \pm 0.017$ \\
\hline$\left(\mathrm{D}_{1}(\mathrm{OH})_{2}+\mathrm{TOH}+\mathrm{AscPH}\right)_{45}$ & 45 & $54.0 \pm 17.0$ & $0.379 \pm 0.015$ \\
\hline
\end{tabular}


Results, obtained about $\mathrm{TOH}$ content $v s$ reaction oxidation time were separated in to the following groups:

$\checkmark$ 0.420-0.470 mg/g TOH content; in this group are samples, in which the $\mathrm{TOH}$ content is equal to the initial $\mathrm{TOH}$ content. Here are $\mathrm{TOH}_{15} ;\left[\mathrm{D}_{1}(\mathrm{OH})_{2}+\mathrm{TOH}\right]_{15} ;\left(\mathrm{M}_{1} \mathrm{OH}+\mathrm{TOH}\right)_{15} ;$ $(\mathrm{TOH}+\mathrm{Asc} \mathrm{PH})_{30} ; \quad\left[\mathrm{D}_{1}(\mathrm{OH})_{2}+\mathrm{TOH}+\mathrm{AscPH}\right]_{30}$ and $\left(\mathrm{M}_{1} \mathrm{OH}+\mathrm{TOH}+\mathrm{Asc} \mathrm{PH}\right)_{20}$;

It was observed that $\mathrm{AscPH}$ exhibited a strong effect as synergist and led to 2-fold longer period (30h), in which the initial TOH content was saved, in comparison with the individual $\mathrm{TOH}$ (15h). Dimer $\mathrm{D}_{1}(\mathrm{OH})_{2}$ and monomer $\mathrm{M}_{1} \mathrm{OH}$ in binary mixtures with $\mathrm{TOH}$ demonstrated the same initial high $\mathrm{TOH}$ content as observed when $\mathrm{TOH}$ was used as an individual compound. Monomer $\mathrm{M}_{1} \mathrm{OH}$ in ternary mixtures with $\mathrm{TOH}$ and AscPH showed the high initial $\mathrm{TOH}$ content for a longer period (20h).

$\checkmark$ 0.340-0.420mg/g TOH content; in this group are samples, in which the $\mathrm{TOH}$ content is high, but lower than the initial TOH content. Here are $\mathrm{TOH}_{20} ; \quad\left(\mathrm{TOH}+\mathrm{M}_{1} \mathrm{OH}\right)_{20}$; $\left.\left[\mathrm{TOH}+\mathrm{D}_{1}(\mathrm{OH})_{2}\right]_{20} ; \mathrm{D}_{1}(\mathrm{OH})_{2}+\mathrm{TOH}+\mathrm{AscPH}\right]_{45}$.

The results obtained after $20 \mathrm{~h}$ oxidation showed that $\mathrm{TOH}$ content is the same for both TOH used alone and for $\mathrm{TOH}$ in binary mixtures of monomer $\mathrm{M}_{1} \mathrm{OH}$ and dimer $\mathrm{D}_{1}(\mathrm{OH})_{2}$. The same $\mathrm{TOH}$ content was observed in the ternary mixture of $\mathrm{D}_{1}(\mathrm{OH})_{2}+\mathrm{TOH}+\mathrm{Asc} \mathrm{PH}$, but after $45 \mathrm{~h}$ of lipid autoxidation. The latest result is of great significance in the search for optimal stabilization of lipid substrate.

$\checkmark$ 0.250-0.340 mg/g TOH content; in this group are samples, with moderate $\mathrm{TOH}$ content. Here are: $\left[\mathrm{D}_{1}(\mathrm{OH})_{2}+\mathrm{TOH}\right]_{30} ;\left(\mathrm{M}_{1} \mathrm{OH}+\mathrm{TOH}\right)_{30}$; $\left(\mathrm{M}_{1} \mathrm{OH}+\mathrm{TOH}+\mathrm{Asc} \mathrm{PH}\right)_{30}$.

It was observed that, after $30 \mathrm{~h}$ oxidation of lipid substrate, the same $\mathrm{TOH}$ content for binary mixtures of $\mathrm{M}_{1} \mathrm{OH}$ and $\mathrm{D}_{1}(\mathrm{OH})_{2}$ with $\mathrm{TOH}$ were obtained, which is equal to those of the mixture of $\mathrm{M}_{1} \mathrm{OH}+\mathrm{TOH}+\mathrm{Asc} \mathrm{PH}$.

$\checkmark$ 0.040-0.120 mg/g TOH content; in this group samples, with the lowest $\mathrm{TOH}$ content.

Only ternary mixture of $\left(\mathrm{M}_{1} \mathrm{OH}+\mathrm{TOH}+\mathrm{Asc} \mathrm{PH}\right)_{45}$ to this group with low content of TOH. For comparison, the ternary mixture of $\mathrm{D}_{1}(\mathrm{OH})_{2}+\mathrm{TOH}+\mathrm{Asc} \mathrm{PH}$, after $45 \mathrm{~h}$ oxidation reaction time, manifested much higher $\mathrm{TOH}$ content, equal to the initial $\mathrm{TOH}$ content. It must be noted that the binary mixtures of $(\mathrm{TOH}+\mathrm{AscPH})_{45}, \quad\left[\mathrm{D}_{1}(\mathrm{OH})_{2}+\mathrm{TOH}\right]_{45} ; \quad$ and $\left(\mathrm{M}_{1} \mathrm{OH}+\mathrm{TOH}\right)_{45}$ showed the same $\mathrm{TOH}$ content after $45 \mathrm{~h}$ oxidation time of lipid substrate, but muchlower in comparison with the ternary mixture of $\mathrm{M}_{1} \mathrm{OH}$.

Complex mechanisms of $\mathrm{TOH}$ regeneration in binary and triple mixtures are presented at

Figure 9 (a-d).

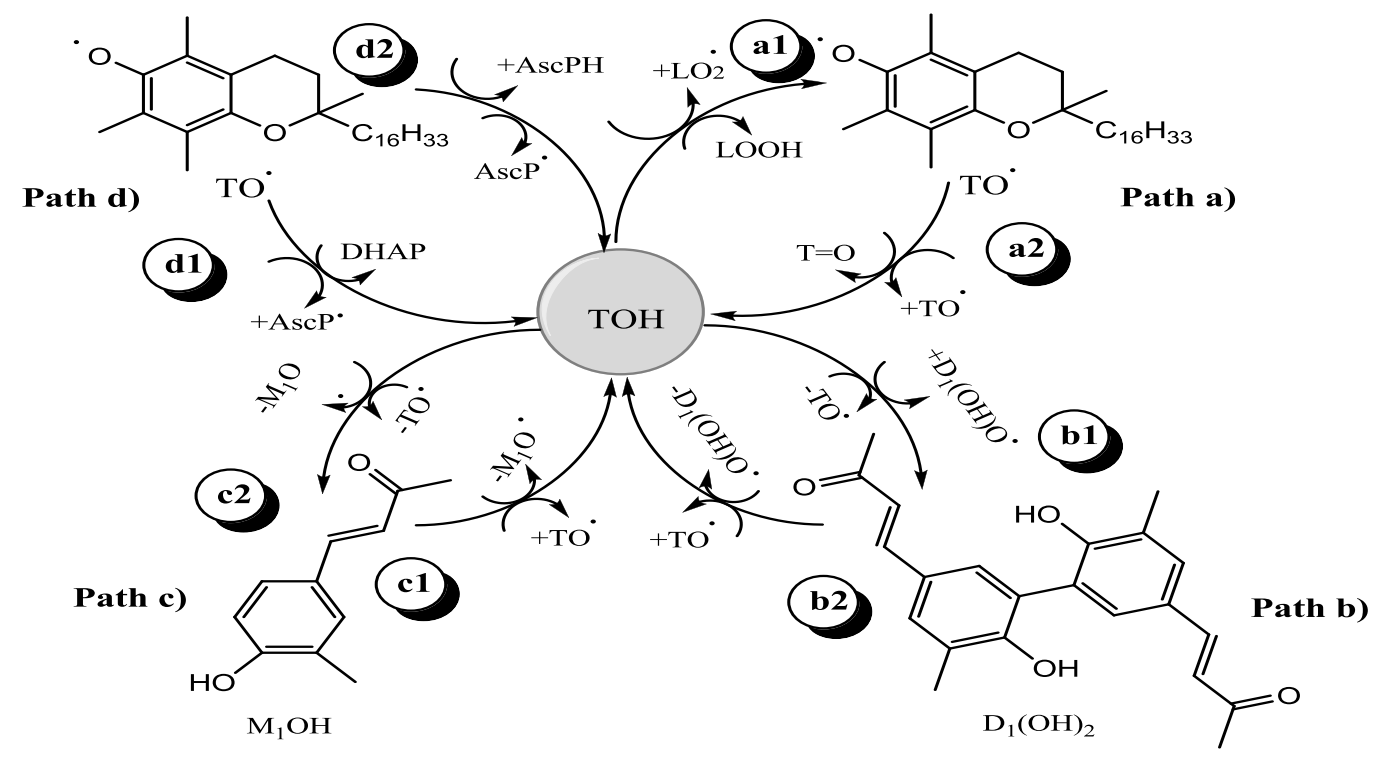

Figure 9a. Complex mechanism of TOH regeneration during lipid autoxidation added as individual antioxidant (Path a) and in double mixtures with $\mathrm{D}_{1}(\mathrm{OH})_{2}$ (Path b), $\mathrm{M}_{1} \mathrm{OH}$ (Path c), and AscPH (Path d) 
Path a): a1) $\mathrm{H}$-atom transfer from $\mathrm{TOH}$ to $\mathrm{LO}_{2} \bullet$ (the key reaction of inhibited oxidation);

a2) Homo-disproportionation of tocopheryl radicals $(\mathrm{TO} \bullet)$ with $\mathrm{TOH}$ regeneration;

Path b): b1) H-atom transfer from TOH to $\mathrm{D}_{1}(\mathrm{OH}) \mathrm{O} \bullet$ with regeneration of $\mathrm{D}_{1}(\mathrm{OH})_{2}$;

b2) $\mathrm{H}$-atom transfer from $\mathrm{D}_{1}(\mathrm{OH})_{2}$ to $\mathrm{TO} \cdot$ with regeneration of $\mathrm{TOH}$;

Path c): c1) $\mathrm{H}$-atom transfer from $\mathrm{M}_{1} \mathrm{OH}$ to $\mathrm{TO} \bullet$ with regeneration of $\mathrm{TOH}$;

c2) $\mathrm{H}$-atom transfer from $\mathrm{TOH}$ to $\mathrm{M}_{1} \mathrm{O} \bullet$ with regeneration of $\mathrm{M}_{1} \mathrm{OH}$;

Path d): d1) Cross-disproportionation between $\mathrm{TO} \bullet$ and $\mathrm{AscP} \bullet$ with regeneration of $\mathrm{TOH}$ And DHAP - dehydroascorbylpalmitate formation;

d2) $\mathrm{H}$-atom transfer from $\mathrm{AscPH}$ to $\mathrm{TO} \bullet$ with regeneration of $\mathrm{TOH}$.

Observed synergism of $\mathrm{M}_{1} \mathrm{OH}+\mathrm{TOH}(32.3 \%)$ is due to the possible regeneration of $\mathrm{TOH}$, as the strongest antioxidant, by reaction of $\mathrm{H}$ atom

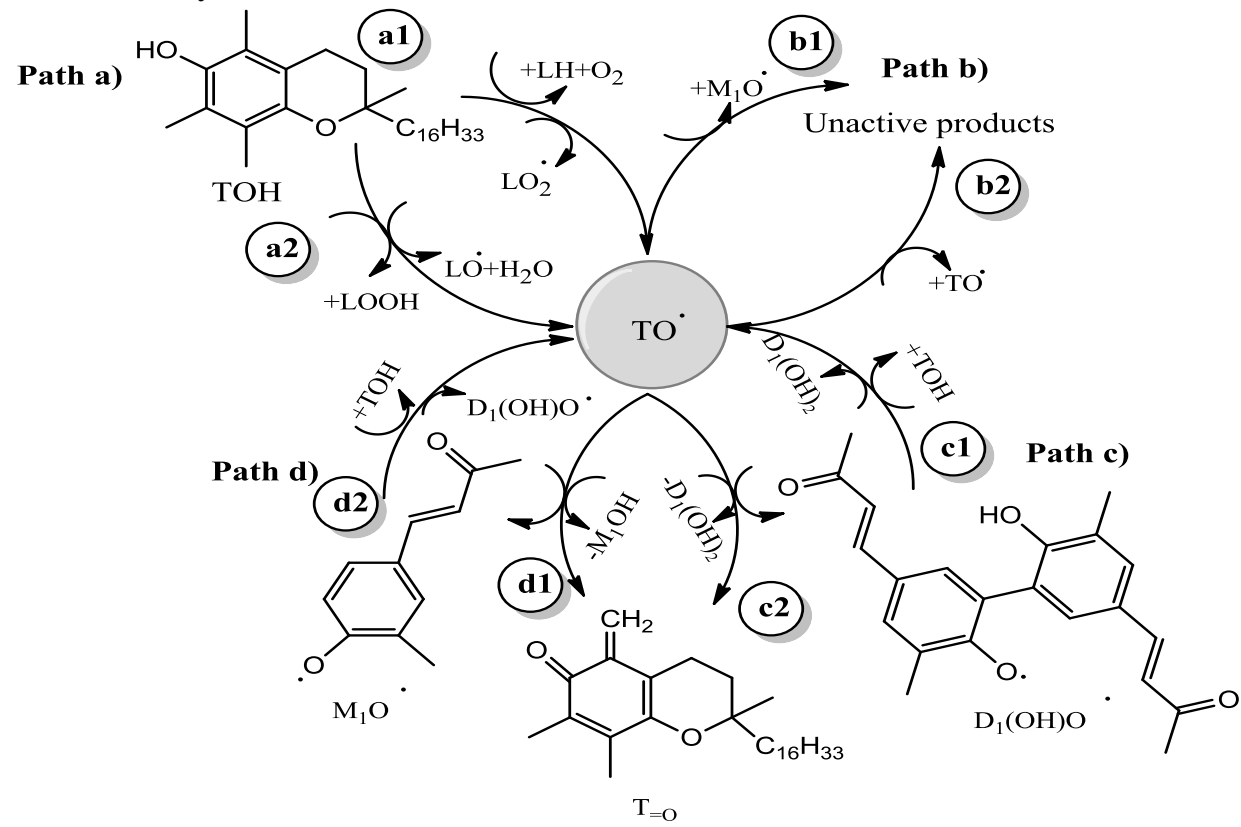

Figure $9 \mathrm{~b}$. Complex mechanism of possible side reactions tocopherol $\mathrm{TOH}$ and its tocopheryl radical $\mathrm{TO}^{\bullet}$ resulting to decrease of TOH activity

Path a): a1) Additional generation of free radicals $\left(\mathrm{LO}_{2}{ }^{\bullet}\right)$ from TOH in reaction with lipid substrate (LH); (at high $\mathrm{TOH}$ concentration - activity of TOH decreases);

a2) $\mathrm{TOH}$ increases decomposition of $\mathrm{LOOH}$ into free radicals (side reaction, reducing activity of $\mathrm{TOH}$ );

Path b): b1) Cross-recombination of tocopheryl radical (TO') and $\mathrm{M}_{1} \mathrm{O}^{\bullet}$ (formation of inactive products);

b2) Homo-recombination of two tocopheryl radicals ( $\left.\mathrm{TO}^{\circ}\right)$ to inactive products;

Path c): c1) H-atom transfer from TOH to $\mathrm{D}_{1}(\mathrm{OH})_{2}$ with regeneration of $\mathrm{D}_{1}(\mathrm{OH})_{2}$;

c2) Cross-disproportionation reaction between $\mathrm{TO}^{\circ}$ and $\mathrm{D}_{1}(\mathrm{OH})_{2}{ }^{\bullet}$ with regeneration of $\mathrm{D}_{1}(\mathrm{OH})_{2}$;

Path d): d1) Cross-disproportionation reaction between $\mathrm{TO}^{\bullet}$ and $\mathrm{M}_{1} \mathrm{O}^{\bullet}$ with regeneration of $\mathrm{M}_{1} \mathrm{OH}$;

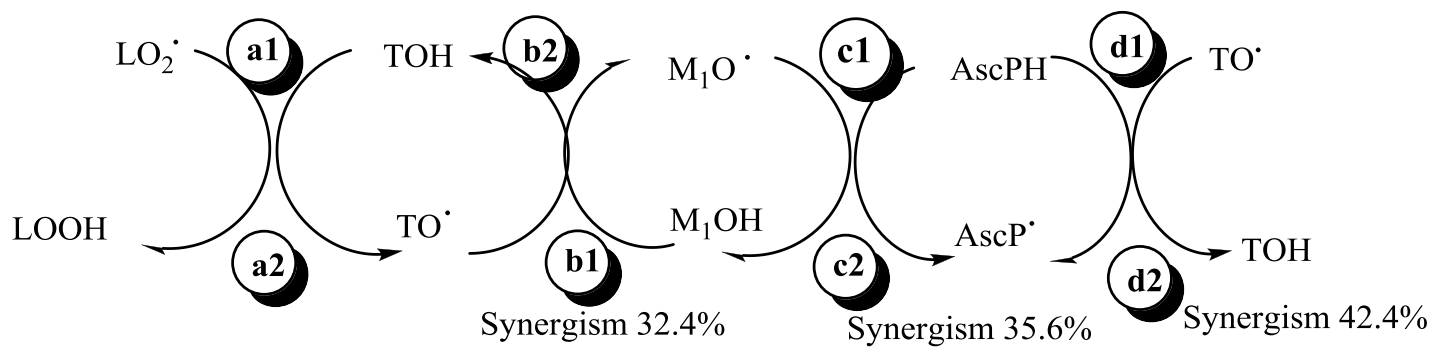

Total synergism of triple mixture $28.7 \%$

Figure 9c. Complex mechanism of synersism obtained between components in triple mixture $\mathrm{M}_{1} \mathrm{OH}+\mathrm{TOH}+\mathrm{AscPH}$ 
Main reactions, responsible to the synergism obtained:

a1) $\mathrm{H}$-atom transfer from $\mathrm{TOH}$ to $\mathrm{LO}_{2} \bullet$ (the key reaction of inhibited oxidation)

b1) $\mathrm{H}$-atom transfer from $\mathrm{M}_{1} \mathrm{OH}$ to $\mathrm{TO} \bullet$ with regeneration of $\mathrm{TOH}$;

c1) $\mathrm{H}$-atom transfer from $\mathrm{AscPH}$ to $\mathrm{M}_{1} \mathrm{O} \bullet$ with regeneration of $\mathrm{M}_{1} \mathrm{OH}$;

d1) $\mathrm{H}$-atom transfer from $\mathrm{AscPH}$ to $\mathrm{TO} \bullet$ with regeneration of $\mathrm{TOH}$;

Additional reactions:

a2) Decomposition of $\mathrm{LOOH}$ by tocopheryl radical (TO•) to $\mathrm{LO}_{2}{ }^{\bullet}$ (decreasing $\mathrm{TOH}$ activity)

b2) $\mathrm{H}$-atom transfer from $\mathrm{TOH}$ to $\mathrm{M}_{1} \mathrm{O} \bullet$ with regeneration of $\mathrm{M}_{1} \mathrm{OH}$;

c2) $\mathrm{H}$-atom transfer from AscPH to $\mathrm{M}_{1} \mathrm{O} \cdot$ with regeneration of $\mathrm{M}_{1} \mathrm{OH}$;

d2) $\mathrm{H}$-atom transfer from $\mathrm{TOH}$ to $\mathrm{AscP} \bullet$ with regeneration of $\mathrm{AscPH}$.

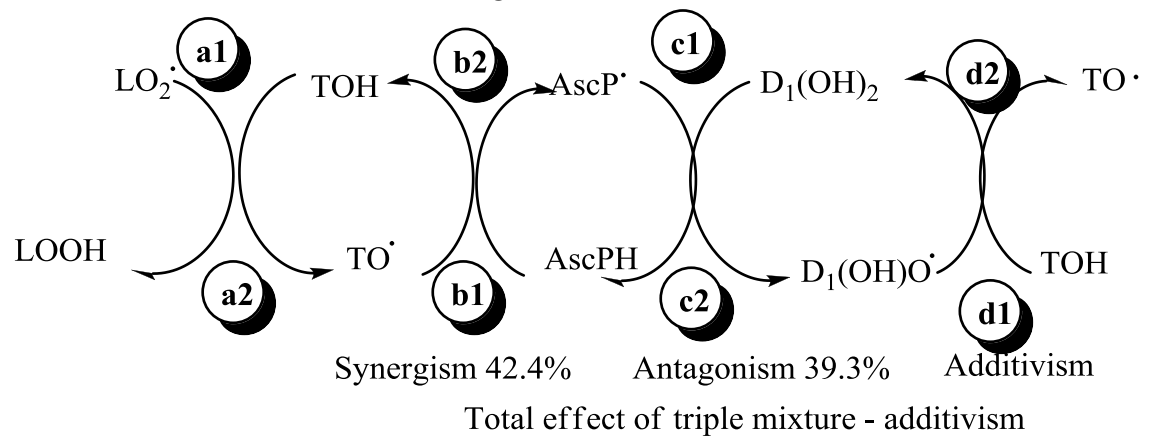

Figure 9d .Complex mechanism of additivism obtained between components in triple mixture $\mathrm{D}_{1}(\mathrm{OH})_{2}+\mathrm{TOH}+$ $\mathrm{AscPH}$

Main reactions, responsible to the synergism obtained:

a1) $\mathrm{H}$-atom transfer from $\mathrm{TOH}$ to $\mathrm{LO}_{2} \bullet$ (the key reaction of inhibited oxidation)

b1) $\mathrm{H}$-atom transfer from $\mathrm{AscPH}$ to $\mathrm{TO} \bullet$ with regeneration of $\mathrm{TOH}$;

c1) $\mathrm{H}$-atom transfer from $\mathrm{D}_{1}(\mathrm{OH})_{2}$ to $\mathrm{AscPH}$ with regeneration of $\mathrm{AscPH}$;

d1) $\mathrm{H}$-atom transfer from $\mathrm{TOH}$ to $\mathrm{D}_{1}(\mathrm{OH}) \mathrm{O} \bullet$ with regeneration of $\mathrm{D}_{1}(\mathrm{OH})_{2}$;

\author{
Additional reactions: \\ a2) Decomposition of $\mathrm{LOOH}$ by tocopheryl radical (TO•) to $\mathrm{LO}_{2}{ }^{\bullet}$ (decrearsing $\mathrm{TOH}$ activity) \\ b2) $\mathrm{H}$-atom transfer from $\mathrm{TOH}$ to $\mathrm{AscPH} \bullet$ with regeneration of $\mathrm{AscPH}$; \\ c2) H-atom transfer from AscPH to $\mathrm{D}_{1}(\mathrm{OH}) \mathrm{O} \bullet$ with regeneration of $\mathrm{D}_{1}(\mathrm{OH})_{2}$; \\ d2) H-atom transfer from $\mathrm{TOH}$ to to $\mathrm{D}_{1}(\mathrm{OH}) \mathrm{O} \bullet$ with regeneration of $\mathrm{D}_{1}(\mathrm{OH})_{2}$.
}

\section{CONCLUDING REMARKS}

Antioxidant activity is capacity of the compound to shorten the oxidation chain length as a result of its reaction with peroxyl radicals. For that reason we mean as antioxidant activity the chainbreaking activity of the compounds.

Synergism between individual components in binary mixtures is explained with differences in $\mathrm{BDE}_{\mathrm{O}-\mathrm{H}}$ and by $\mathrm{H}$ atom abstraction and crossdisproportionation reaction, leading to regeneration of the most powerful antioxidant.

Additivism is found for antioxidants with close $\mathrm{BDE}_{\mathrm{O}-\mathrm{H}}$ and similar power.

Antagonism is found for antioxidants with lower $\mathrm{BDE}_{\mathrm{O}-\mathrm{H}}$ than of $\mathrm{TOH}$ and when regeneration of antioxidants is not possible during the reaction of cross-recombination of both phenoxyl radicals. Structural characteristics of the complex system: oxidizing substrate-antioxidant must be considered. On the basis of this comparative analysis, the most effective individual antioxidants and binary mixtures were proposed for the highest and optimal lipid oxidation stability. The latest is of importance for the practice.

\section{REFERENCES}

1. E.B. Burlakova, Bioantioxidants, Russ. Chem. J., 51, 3-12, 2007.

2. V.D. Kancheva, \& O.T. Kasaikina, Bioantioxidants - a chemical base of their antioxidant activity and beneficial effect on human health, Current Medicinal Chemistry, 20, 4784-4805, 2013.

3. V.Kancheva, Oxidative Stress and Lipid Oxidation, in: "Antioxidants - Prevention and Healthy Aging", Ed. by F.Ribarova, SIMELPRESS Publ., Sofia, Bulgaria, Chapter 3, 233-238, 2010.

4. V.D.Kancheva, Phenolic Antioxidants of Natural Origin - Structure Activity Relationship and their Beneficial Effect on 
Human Health. In: "Phytochemicals and Human Health: Pharmacological and Molecular Aspects", Nova Science Publishers Inc., USA, Ed. A.A.Farooqui, 2011, Chapter I, $1-45$

5. V.D.Kancheva, R.Taskova, I.Totseva, N.Handjieva; Antioxidant Activity of Extracts, Fractions and Flavonoid Constituents from Carthamus lanatus L., Riv. Ital. delle Sost. Grasse, 84, 77-86, 2007.

6. V.D.Kancheva, L.Saso, P.V.Boranova, M.K.Pandey, Sh.Malhorta, J.T.Nechev, A.K.Prasad, M.B.Georgieva, A.L.DePass, V.S.Parmar, Structure-Activity Relationship of Some Dihydroxy Coumarins. Correlation Between Experimental and Theoretical Data and Synergistic Effect. BIOCHIMIE, 92 (9), 1089-1100, 2010.

7. V.D.Kancheva, A. Slavova-Kasakova, D.Fabbri, S.Angelova, M.A.Dettori, J.Nechev, G.Delogu, Antiradical and Antioxidant Activities of New Natural-like Biphenyls of Zingerone, Dehydrozingerone and Ferulic Acid, Comp. Rend. Acad. Bulg. Sci., 66 (3), 361-369, 2012.
8. V.D.Kancheva, A.Slavova-Kazakova, D.Fabbri, M.A. Dettori. G. Delogu, M.Janek, R. Amarowicz, Protective effects of equimolar mixtures of dehydrozingerone and its dimer with $\alpha$-tocopherol and/or ascorbylpalmitate during lipid autoxidation, Food Chem, 157, 263-274, 2014.

9. V.D.Kancheva, Phenolic Antioxidants Radical Scavenging and Chain Breaking Activities. Comparable study. Eur J Lipid Sci Technol., 111 (11), 1072-1089, 2009.

10.R.Torres, F.Faini, B.Modak, F.Urbina, C.Labbe, Y.Guerro, Antioxidant activity of coumarins and flavonoids from the resinous exudates of Haplopappus multifolines, Phytochemistry, 67, 984-987, 2006.

11.E.T.Denisov, T.G. Denisova, Handbook of antioxidants, bond dissociation energies, rate constants, activation energies and enthalpies of reactions. New York: CRS Press, 2001.

12.A.Marchiani, C.Rozzo, A. Fadda, G.Delogu, R. Ruzza, R. Curcumin and curcumin-liked molecules from spice to drugs. Current Medicinal Chemistry, 21, 204-222, 2014. 